European Journal of

Organic Chemistry
Postfach 101161 69451 Weinheim

Germany

Courier services:

Boschstraße 12

69469 Weinheim

Germany

Tel.: (+49) 6201606255

Fax: (+49) 6201606203

E-mail: eurjoc@wiley-vch.de

Manuscript No.

\section{Reprints/lssues}

You are entitled to a PDF for 25 hardcopies of your article. You also have the opportunity to order further issues, reprints, posters or a PDF for an unlimited number of hardcopies at the quoted rates.

Reprints of European Journal of Organic Chemistry articles are very popular. Whole issues, reprints, posters and high-quality PDFs are available at the rates given on a separate sheet. There is no surcharge for color reprints.

For overseas orders please note that you will receive your issues, reprints or posters by airmail unless you specifically opt for receiving them by surface mail. An appropriate surcharge will be levied to cover the higher postal rates.

Please bill me for:

\section{Reprints}

$$
\text { (quantity) }
$$

\section{Issues}

$$
\text { (quantity) }
$$

and send them by

$\square$ surface mail $\square$ courier service

\section{Cover Posters}

Posters are available of all the published covers in two sizes (see attached price list).

DIN A2 (42 x $60 \mathrm{~cm} / 17 \times 24 \mathrm{in})$ :

$\square$ front cover $\square$ back cover

DIN A1 (60 x 84 cm/ 24 x 33in):

$\square$ front cover $\square$ back cover

\section{PDF (unlimited number of hardcopies)}

\section{Please bill me for}

$\square$ a PDF file (high resolution)

\section{E-mail address}

Please note that posting of the final published version on the open internet is not permitted but it can be forwarded to colleagues, added to promotion packages, etc.

$\star$ Special Offer $\star$ If you order 200 or more reprints you will get a PDF file for half-price. reprints and a PDF file

Mail reprints/ issues/ posters to (no P.O. Boxes)

\section{Terms of Payment}

\section{Send INVOICE to}

\section{VAT number}

Tax-free charging can only be processed with the VAT number of the institute/company. To prevent delays with the processing, please provide us with the VAT number with this order.

\section{Purchase Order No.:}

\section{Charge the CREDIT CARD}

We accept

\section{VISA}
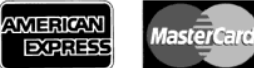

For your security please create a secured Credit Card Token which is a combination of numbers and letters that is used instead of the credit card information. Click here:

https://www.wiley-vch.de/editorial production/index.php

TOKEN

Date, Signature 


\section{Price List (2017)}

The prices listed below are valid only for orders received in the course of 2017. Minimum order is 50 copies. Delivery time will be approximately 3 weeks after the date of publication.

If more than 500 copies are ordered, special prices are available upon request.

Printed issues are available on demand. The prices are exclusive of VAT and mailing and handling charges. Reprints, issues and posters for overseas orders are shipped by airmail (25.00 Euro surcharge). If you would like to receive them by surface mail please indicate this on the accompanying order form (postage for shipping posters within Europe: 15.00 Euro). If you would like to use a courier service please indicate this on the order form. The cost for the courier service is 75.00 Euro.

\section{Information regarding VAT}

The charges for Reprints, Issues or Posters are considered to be "supply of goods" and therefore subject to German VAT. However, if you are an institutional customer outside Germany, the tax can be waived if you provide us with the VAT number of your company. Non-EU customers may have a VAT number starting with "EU" instead of their country code if they are registered with the EU tax authorities. If you do not have an EU VAT number and you are a taxable person doing business in a non-EU country, please provide certification from your local tax authorities confirming that you are a taxable person under local tax law. Please note that the certification must confirm that you are a taxable person and are conducting an economic activity in your country. Note: certifications confirming that you are a tax-exempt legal body (non-profit organization, public body, school, political party, etc.) in your country do not exempt you from paying German VAT.

\begin{tabular}{|c|c|c|c|c|c|c|}
\hline \multirow{2}{*}{$\begin{array}{l}\text { Reprints } \\
\text { Size (pages) }\end{array}$} & \multicolumn{6}{|c|}{ Price for orders (in Euro) } \\
\hline & 50 copies & 100 copies & 150 copies & 200 copies & 300 copies & 500 copies \\
\hline $1-4$ & 345.- & 395.- & 425.- & 445.- & 548.- & 752.- \\
\hline $5-8$ & 490.- & 573.- & 608.- & 636.- & 784.- & 1077.- \\
\hline $9-12$ & 640.- & 739.- & 786.- & 824.- & 1016.- & 1396.- \\
\hline $13-16$ & 780.- & 900.- & 958.- & 1004.- & 1237.- & 1701.- \\
\hline $17-20$ & 930.- & 1070.- & 1138.- & 1196.- & 1489.- & 2022.- \\
\hline $\begin{array}{l}\text { for every additional } \\
4 \text { pages }\end{array}$ & 147.- & 169.- & 175.- & 188.- & 231.- & 315.- \\
\hline
\end{tabular}

\section{Issues (available $\quad 68 €$ per copy (5 copies or less). For higher print runs, please send on demand) a request to chem-reprints@wiley.com}

\section{PDF (high resolution) 330 Euro}

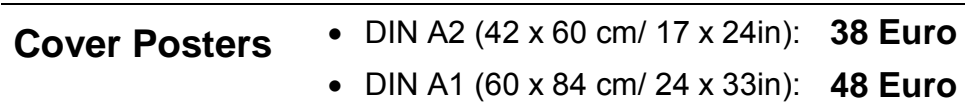

\section{$\star$ Special Offer $\star$}

If you order 200 or more reprints you will get a PDF (high resolution) for half-price. 


\title{
Origin of the Base-Dependent Facial Selectivity in Annulation Reactions of Nazarov-Type Reagents with Unsaturated Indolo[2,3-a]quinolizidine Lactams
}

\author{
Carolina Estarellas, ${ }^{[a]}$ Federica Arioli, ${ }^{[b]}$ Maria Pérez, ${ }^{[a]}$ Celeste Are, ${ }^{[b]}$ David Hevia, ${ }^{[b]}$

Abstract: Methyl-substituted Nazarov reagent $\mathbf{4}$ reacts stereoselectively with $N_{\text {ind }}$-Boc indoloquinolizidine lactams to give the expected $3-\mathrm{H} / 15-\mathrm{H}$ cis pentacyclic yohimbine-type adducts when using 1,8-diazabicyclo[5.4.0]undec-7-ene (DBU) as the 1 base. However, a dramatic change of the facial selectivity was observed when the reaction was performed in the presence of
$\mathrm{Cs}_{2} \mathrm{CO}_{3}$, leading to the corresponding trans adducts. This annulation is the key step of a stereocontrolled synthesis of the 17acarba analogue of the heteroyohimbine alkaloid akuammigine. Theoretical calculations were used to rationalize the facial selectivity of these double Michael addition reactions.

\section{Introduction}

Ethyl (or methyl) 3-oxo-4-pentenoate (1), known as the Nazarov reagent, ${ }^{[1]}$ is a versatile annulating agent that is widely used in

21 a variety of Robinson-type annulations, in which it sequentially acts as an electrophilic reagent in a Michael addition and as a nucleophile to promote the cyclization ${ }^{[2,3]}$ (Scheme 1). The fact that $\mathbf{1}$ is unstable under basic conditions and polymerizes ${ }^{[4]}$

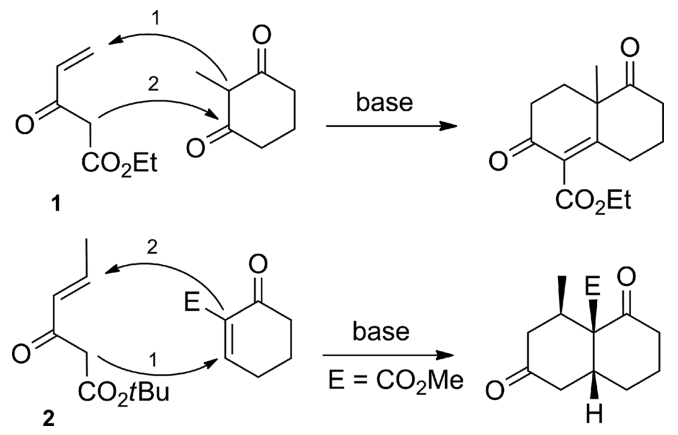

Scheme 1. Typical reactivity of the Nazarov reagent (1) and its methyl-substituted analogue $\mathbf{2}$.

[a] Department of Nutrition, Food Sciences and Gastronomy, Faculty of Pharmacy and Food Sciences, and Institute of Biomedicine (IBUB), University of Barcelona,

08921 Santa Coloma de Gramanet, Spain

E-mail: fjluque@ub.edu www.ub.edu/cbdd

[b] Laboratory of Organic Chemistry, Faculty of Pharmacy and Food Sciences, and Institute of Biomedicine (IBUB), University of Barcelona, 08028 Barcelona, Spain

E-mail: amat@ub.edu www.ub.edu/sintefarma

[c] Institut de Ciència de Materials (CSIC) Campus UAB, 08193 Cerdanyola, Spain

Supporting information and $O R C I D(s)$ from the author(s) for this article are available on the WWW under https://doi.org/10.1002/ejoc.201700610. rapidly at room temperature has stimulated the development of more stable analogues of $\mathbf{1}$ bearing alkyl substituents on the 26 vinyl moiety, such as 2. ${ }^{[5]}$ These Nazarov-type reagents are able to undergo alternative annulations involving base-catalyzed double Michael addition reactions with $\alpha, \beta$-unsaturated carbonyl compounds, in which the reagent successively acts as a nucleophile and an electrophilic Michael acceptor. ${ }^{[6]}$

In previous work ${ }^{[7]}$ we have reported the preparation of the silylated derivative $\mathbf{3}$, which behaves as a stable synthetic equivalent of the original Nazarov reagent 1. Derivative $\mathbf{3}$ can participate in base-promoted double Michael annulations (Scheme 2), avoiding the polymerization problem associated 36 with 1. Using unsaturated indolo[2,3-a]quinolizidine lactams $\mathbf{A}$, this reagent opened up straightforward stereodivergent routes to yohimbine-type derivatives. ${ }^{[7,8]}$ Interestingly, pentacyclic 3$\mathrm{H} / 15-\mathrm{H}$ trans adducts $\mathbf{B}$ were generated from $N_{\text {ind }}$-unsubstituted

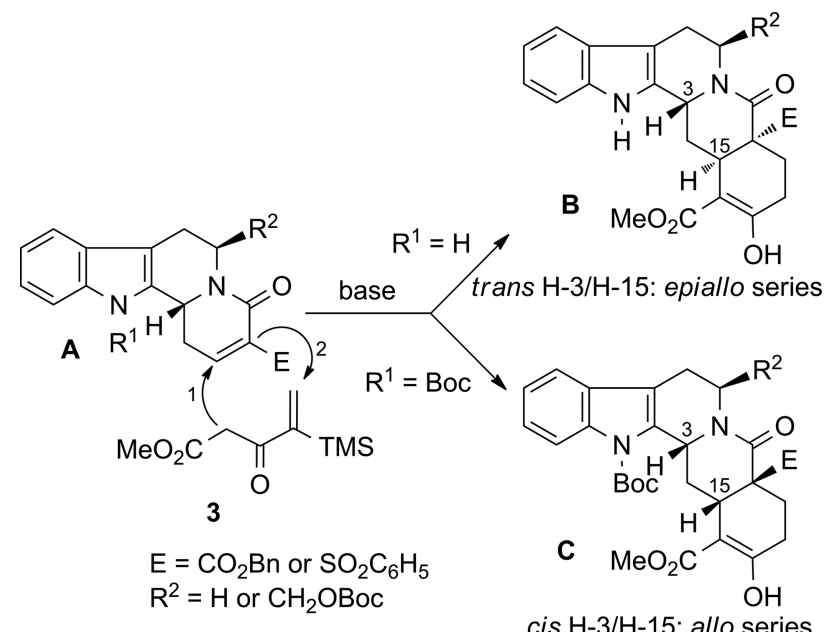

cis $\mathrm{H}-3 / \mathrm{H}-15$ : allo series

Scheme 2. Stereocontrolled annulations with the silylated Nazarov reagent 3. 
41 lactams, but the corresponding cis isomers $\mathbf{C}$ were formed when the indole nitrogen atom bears a Boc substituent (Scheme 2). ${ }^{[9]}$ This dramatic reversal in the facial selectivity was rationalized based on theoretical calculations, which indicated that the initial nucleophilic attack under stereoelectronic con-

46 trol is hampered by the presence of the bulky Boc group. ${ }^{[8]}$ The reactions were performed using either 1,8-diazabicyclo[5.4.0]undec-7-ene (DBU) [in tetrahydrofuran (THF) ${ }^{[10]}$ or $\mathrm{Cs}_{2} \mathrm{CO}_{3}$ (in $\mathrm{CH}_{2} \mathrm{Cl}_{2}$ ) as the base, although with the latter, when $\mathrm{E}=\mathrm{SO}_{2} \mathrm{C}_{6} \mathrm{H}_{5}$, the stereoselectivity was lower and dependent on

51 the concentration of $\mathrm{Cs}_{2} \mathrm{CO}_{3}$.

On the basis of these findings, we envisaged that the use of the methyl-substituted Nazarov reagent 4 (Scheme 3) in double Michael annulations with unsaturated indolo[2,3-a]quinolizidine lactams A would afford pentacyclic carba analogues of

56 heteroyohimbine alkaloids bearing their characteristic C-19 methyl substituent (Figure 1). By following this rationale, we report here the enantioselective synthesis of 17a-carbaakuammigine, taking advantage of an unexpected base-dependent stereoselective addition in double Michael annulations with

61 Nazarov reagent 4. Furthermore, theoretical calculations allow us to justify the facial selectivity of these reactions and to disclose the key role played by cesium cations in directing the stereoselective outcome.

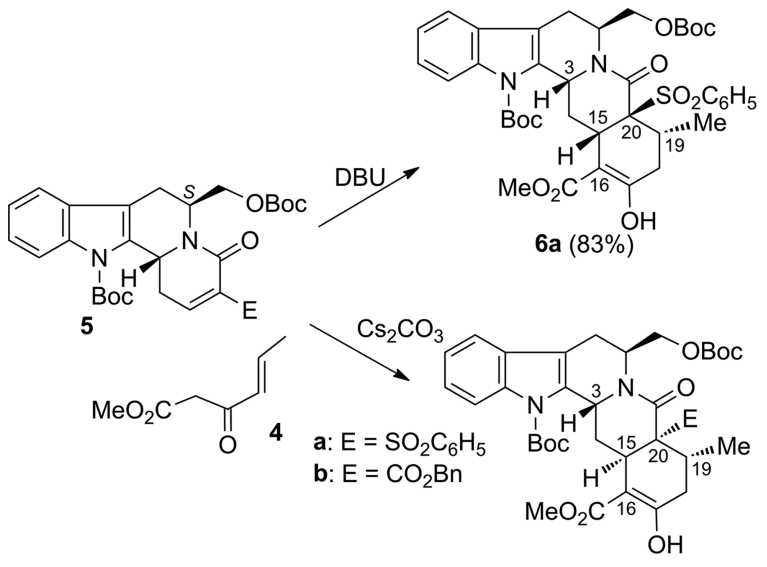

$7 \mathbf{a}(86 \%), 7 \mathbf{b}(87 \%)$

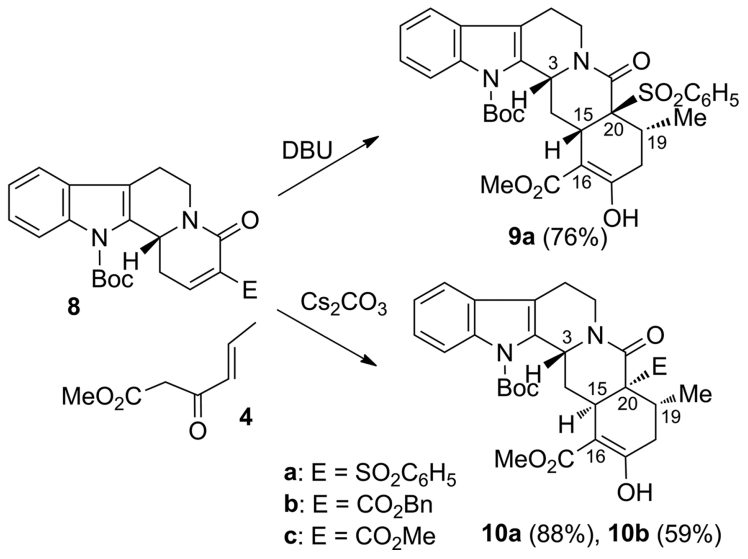

Scheme 3. Double Michael addition reactions of the methyl-substituted Nazarov reagent $\mathbf{4}$ with unsaturated lactams $\mathbf{5}$ and $\mathbf{8}$ (compounds 8-10 are racemic mixtures).

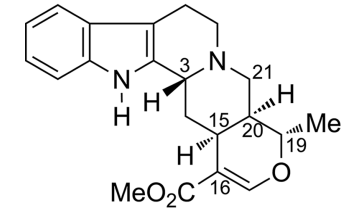

Akuammigine

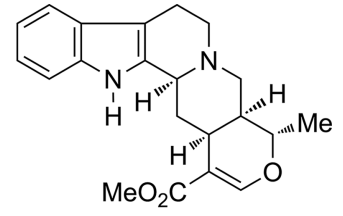

Tetrahydroalstonine
Figure 1. Heteroyohimbine alkaloids akuammigine and tetrahydroalstonine.

\section{Results and Discussion}

Base-Dependent Stereoselective Double Michael Addition Reactions with Nazarov Reagent 4

Reaction of enantiopure $N_{\text {ind }}$-Boc lactam 5 a with Nazarov reagent 4 using DBU as base afforded pentacyclic adduct $\mathbf{6 a}$, with the expected $3-\mathrm{H} / 15-\mathrm{H}$ cis configuration, in excellent yield. ${ }^{[1]}$ However, to our surprise, when the reaction was performed in 71 the presence of $\mathrm{Cs}_{2} \mathrm{CO}_{3}$, which is the most commonly used base for the generation of the enolate salt of Nazarov reagents, the $3-\mathrm{H} / 15-\mathrm{H}$ trans adduct $7 \mathrm{a}$ was obtained in $86 \%$ yield. A similar unexpected stereochemical result was observed in the $\mathrm{Cs}_{2} \mathrm{CO}_{3}$ promoted double Michael addition of $\mathbf{4}$ to unsaturated lactam 76 5b: the pentacyclic $3-\mathrm{H} / 15-\mathrm{H}$ trans adduct $\mathbf{7 b}$ was obtained in $87 \%$ yield (Scheme 3 ).

To further investigate the influence of the base on the facial selectivity of the process, we also studied the annulations of Nazarov reagent 4 with racemic $N_{\text {ind }}$-Boc indoloquinolizidin-2- 81 ones $\mathbf{8} \mathbf{a}$ and $\mathbf{8 b}$, which lack the protected hydroxymethyl substituent. From a stereochemical standpoint, the results matched those previously observed from $\mathbf{5}$. When the reaction of $\mathbf{8 a}$ was performed in the presence of $\mathrm{DBU}$, the $3-\mathrm{H} / 15-\mathrm{H}$ cis pentacycle 9a was obtained in excellent yield. ${ }^{[11]}$ In contrast, when $\mathrm{Cs}_{2} \mathrm{CO}_{3} 86$ was used as the base, the corresponding $3-\mathrm{H} / 15-\mathrm{H}$ trans adducts $\mathbf{1 0 a}$ and $\mathbf{1 0 b ^ { [ 1 2 ] }}$ were formed stereoselectively in $88 \%$ and $59 \%$ yield, respectively.

In agreement with a stepwise double Michael process, when the $\mathrm{Cs}_{2} \mathrm{CO}_{3}$-promoted reaction from $\mathbf{5 a}$ was stopped after $2 \mathrm{~h}, 91$ the tetracyclic intermediate $\mathbf{D}\left(\mathrm{R}=\mathrm{CH}_{2} \mathrm{OBoc}\right)$, arising from the initial Michael addition, was isolated in $23 \%$ yield (Figure 2). Minor amounts of similar open intermediates were detected by NMR spectroscopic analysis in all the annulations shown in Scheme 3, including the reactions in the presence of DBU.

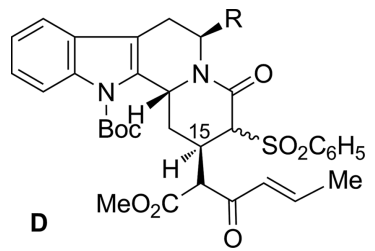

Figure 2. Tetracyclic intermediate D.

The observation of positive NOE effects between 3-H/15- $\mathrm{H}$, C19-Me/ $\mathrm{H \alpha}-14$, and $\mathrm{C} 19-\mathrm{Me} / \mathrm{H} \alpha-18$ in $\mathbf{6 a}$ and $\mathbf{9 a}$, and between $3-\mathrm{H} / 19-\mathrm{H}, 3-\mathrm{H} / \mathrm{H} / 3-18, \mathrm{C} 19-\mathrm{Me} / 15-\mathrm{H}$, and $\mathrm{C} 19-\mathrm{Me} / \mathrm{H} \alpha-18$ in 10a is in agreement with the stereochemical assignments made for the above pentacyclic derivatives. Additionally, the relative con- 101 figuration of $9 \mathrm{a}$ and $10 \mathrm{a}$ was unambiguously established by Xray crystallographic analysis ${ }^{[13]}$ (Figure 3 ). 

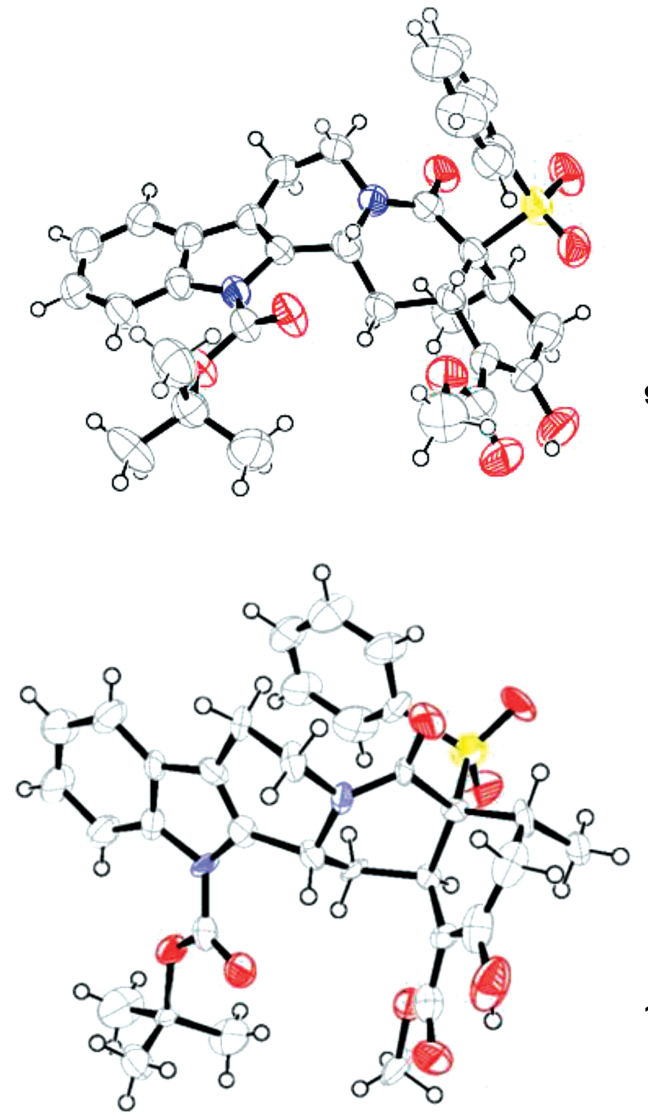

$10 a$

Figure 3. X-ray crystal structures of the $3-\mathrm{H} / 15-\mathrm{H}$ cis and trans adducts $9 \mathrm{a}$ and $\mathbf{1 0 a}$, respectively.

Another striking aspect from the stereochemical standpoint was the relative configuration of the $\mathrm{C}-19$ stereocenter. Whereas 106 the expected cis relative configuration for the substituents at positions 19 and 20 was observed in the $3-\mathrm{H} / 15-\mathrm{H}$ trans adducts 7 and $10,{ }^{[14]}$ a trans $\mathrm{C} 19-\mathrm{Me} / \mathrm{C} 20-\mathrm{SO}_{2} \mathrm{C}_{6} \mathrm{H}_{5}$ relationship was found in the $3-\mathrm{H} / 15-\mathrm{H}$ cis pentacycles $\mathbf{6 a}$ and $\mathbf{9 a} \mathbf{a}^{[15]}$ In all cases, the resulting cis $\mathrm{D} / \mathrm{E}$ ring junction arises from stereoelectronic 111 control during the Michael cyclization step. ${ }^{[6 b, 15 b]}$
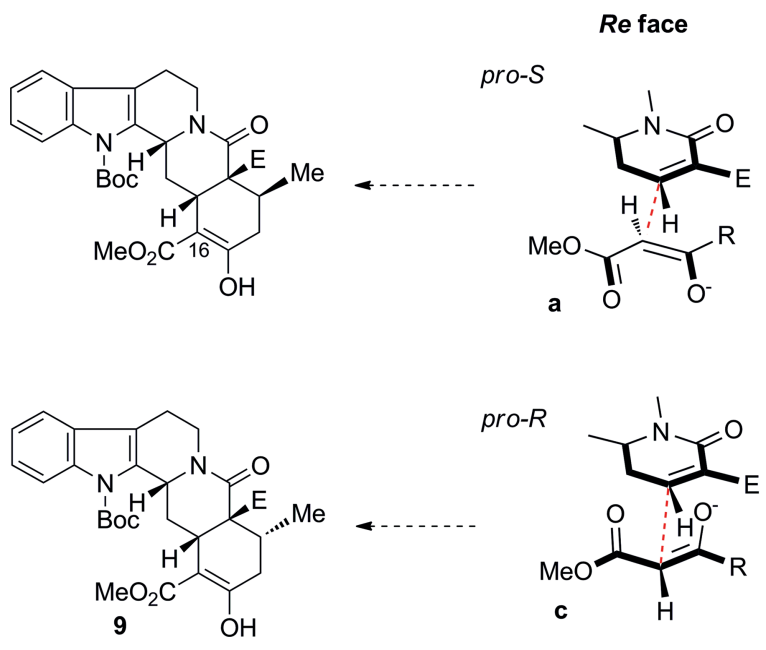

\section{Conformational Preferences of Nazarov Reagents 3 and 4}

Theoretical calculations were performed to understand the unexpected reversal of the facial selectivity of $\mathrm{Cs}_{2} \mathrm{CO}_{3}$-catalyzed annulation reactions of methyl-substituted Nazarov reagent 4 with unsaturated $N_{\text {ind }}$-Boc indoloquinolizidine lactams 5 and 8116 as compared with similar reactions catalyzed by DBU. Calculations were performed using the M06-2X density functional ${ }^{[16]}$ and the $6-31 \mathrm{G}(\mathrm{d})$ basis set, ${ }^{[17]}$ and solvent effects were accounted for by using the SMD version ${ }^{[18]}$ of the IEFPCM model (see the Experimental Section for details).

In a preliminary step, the conformational preference of the anionic species generated from Nazarov reagents $\mathbf{3}$ and $\mathbf{4}$ was determined (Figure S1 in the Supporting Information). The results point out that the $\mathrm{s}$-cis species of $\mathbf{3}$ is favored by $1.7 \mathrm{kcal} /$ mol in $\mathrm{CH}_{2} \mathrm{Cl}_{2}$ relative to the s-trans conformer. It is worth not- 126 ing that the $s$-cis conformation has the appropriate arrangement required for the annulation reaction that gives rise to fused pentacyclic products (B and $\mathbf{C}$ in Scheme 2). In contrast, the $s$-cis species of $\mathbf{4}$ is destabilized by $2.4 \mathrm{kcal} / \mathrm{mol}$ relative to the s-trans conformation, which suggests that the population 131 of the s-cis species is less than $2 \%$ at $298 \mathrm{~K}$. Accordingly, the reaction of $\mathbf{4}$ should primarily proceed through attack of the $s$ trans species, which does not have the configuration required for ring closure. Therefore, it can be expected that the double Michael addition occurs through an intermediate step that in- 136 volves conversion into the s-cis arrangement.

\section{Double Michael Additions with Silylated Nazarov Reagent 3}

To rationalize the stereochemical outcome of the double Michael addition reactions, we first determined the free-energy profile for the reaction of the anionic form of $\mathbf{3}$ to lactam A 141 (Scheme 2, with $\mathrm{R}^{1}=\mathrm{Boc}, \mathrm{R}^{2}=\mathrm{H}$, and $\mathrm{E}=\mathrm{CO}_{2} \mathrm{Me}$ in calculations; $\mathbf{8 c}$ in Scheme 3) as a reference system. Calculations were performed for the Michael additions through the Si and Re faces of lactam $\mathbf{8 c}$. Furthermore, the addition reaction was considered to occur through the two faces of reagent $\mathbf{3}$ (denoted pro-S and 146 pro- $R$ depending on the stereochemistry of the C-16 stereocen-
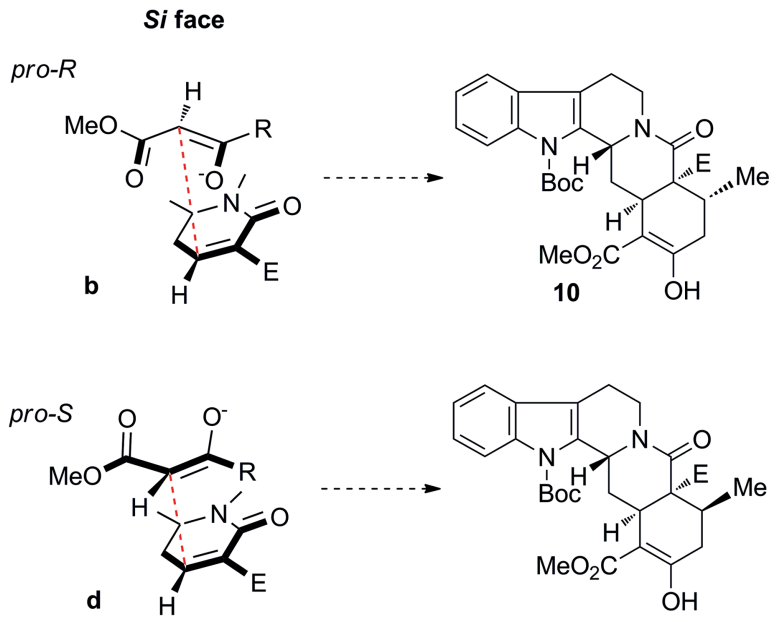

Scheme 4. Representation of the four plausible pathways for the initial Michael addition reactions between the Nazarov reagent $\left\{\mathbf{3}\left[\mathrm{R}=\mathrm{C}(\mathrm{TMS})=\mathrm{CH} \mathrm{H}_{2}\right.\right.$ or $\mathbf{4}$ $[\mathrm{R}=(E)-\mathrm{CH}=\mathrm{CHMe}]\}$ and the lactam, and the resulting possible annulation products formed from the reaction with 4 . 
ter initially formed in the first Michael addition), thus leading to four plausible reaction channels that are schematically shown in Scheme 4. For the specific case of the reaction between rea151 gent $\mathbf{3}$ and lactam $\mathbf{8 c}$, however, the steric hindrance arising from the TMS group allowed us to limit calculations to only two reactive pathways, as will be explained below.

The stereoselective formation of the cis $3-\mathrm{H} / 15-\mathrm{H}$ isomer (C in Scheme 2) stems from the preferential attack of the silylated 156 reagent 3 (pro-S face) through the Re face. This is reflected in the lower stability of the transition state (TS1) formed in the first Michael addition through the Si face, which is destabilized by $3.1 \mathrm{kcal} / \mathrm{mol}$ relative to the Re attack (Figures 4 and 5). This process is the rate-limiting step of the annulation reaction, be-

161 cause the barrier $(8.2 \mathrm{kcal} / \mathrm{mol})$ for the first Michael addition is higher than the barrier required for ring closure $(6.1 \mathrm{kcal} / \mathrm{mol}$; TS2), which ultimately leads to a large stabilization of the annulated product (by nearly $24 \mathrm{kcal} / \mathrm{mol}$ relative to the pre-reactant complex). It is worth noting that the free-energy profile deter-

166 mined from M062X computations is supported by similar freeenergy differences between pre-reactant, intermediate, and transition states obtained from single-point calculations at the SCS-MP2/6-31G(d) and B2PLYP-D3/def2-SVPP levels, as noted from the data reported in Table 1.

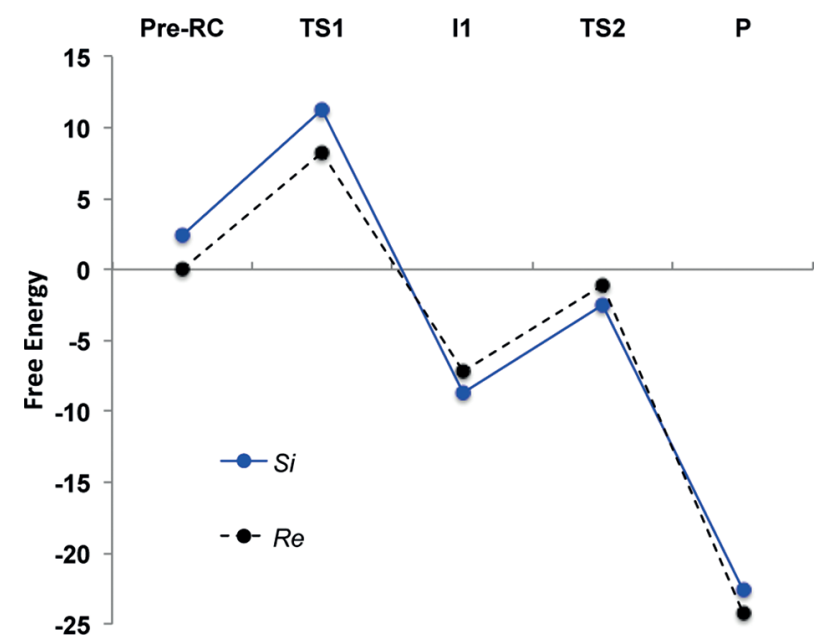

Figure 4. Free energy [ $\mathrm{kcal} / \mathrm{mol}]$ profile for the double Michael addition of the anionic species of Nazarov reagent 3 (pro-S and pro- $R$ faces for $R e$ and $S i$ attacks, respectively) to lactam $8 c$ derived from $M 062 X / 6-31 G(d)$ calculations in $\mathrm{CH}_{2} \mathrm{Cl}_{2}$.

171 Assuming that these reactions are under Curtin-Hammett control, the relative free energy of the transition states (TS1), which is estimated to be around $3 \mathrm{kcal} / \mathrm{mol}$ (see Table 1), would lead to a ratio of 160:1 for the $3-\mathrm{H} / 15-\mathrm{H}$ cis and trans isomers $\mathbf{C}$ and $\mathbf{B}$, respectively (Scheme 2 ), in agreement with the experi-

176 mental data. Inspection of the rate-limiting transition state for the Re addition (Figure 5) suggests that the steric hindrance of the bulky $\mathrm{N}$-Boc group counterbalances the stereochemical preference for attack through the convex face of the $\alpha, \beta$-unsaturated lactam. Furthermore, Figure 6 shows the asynchronicity 181 of the double Michael addition, as the length of the forming C...C bonds is 2.29 and $3.27 \AA$. Finally, Figure 6 also shows that the attack occurs with an antiperiplanar arrangement (a, Scheme 4) of the carbon atoms involved in the first Michael

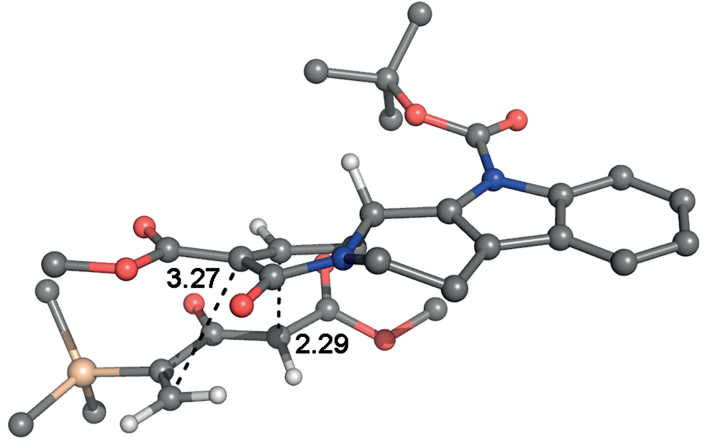

Figure 5. Representation of the transition state (TS1) formed in the Re attack of reagent $\mathbf{3}$ (pro-S face) to lactam $\mathbf{8 c}$. For clarity, only selected hydrogen atoms are shown. Complete geometrical data of pre-reactants, transition states, and intermediates are available in the Supporting Information.

Table 1. Comparison of the free-energy differences $[\mathrm{kcal} / \mathrm{mol}]$ determined at the M062X/6-31G(d), SCS-MP2/6-31G(d), and B2PLYP-D3/def2-SVPP levels in $\mathrm{CH}_{2} \mathrm{Cl}_{2}$ for the addition of the anionic form of Nazarov reagent 3 (pro-S and pro- $R$ faces for $R e$ and $S i$ attacks, respectively) to lactam $\mathbf{8 c}$.

\begin{tabular}{ccccccc}
\hline & \multicolumn{2}{c}{ M062X } & \multicolumn{2}{c}{ SCS-MP2 } & \multicolumn{2}{c}{ B2PLYP-D3 } \\
& $R e$ & $S i$ & $R e$ & $S i$ & $R e$ & $S i$ \\
\hline Pre-RC & 0.0 & 2.5 & 0.0 & 3.1 & 0.0 & 2.7 \\
TS1 & 8.2 & 11.3 & 11.5 & 14.9 & 7.3 & 10.1 \\
I1 & -7.2 & -8.7 & -9.7 & -11.0 & -8.0 & -9.5 \\
TS2 & -1.1 & -2.5 & -3.1 & -4.7 & -5.5 & -6.6 \\
P & -24.2 & -22.6 & -30.6 & -29.4 & -29.0 & -26.6 \\
\hline
\end{tabular}

addition $\left(\mathrm{H}-\mathrm{C} . . . \mathrm{C}-\mathrm{H}\right.$ dihedral angle $\left.-172.8^{\circ}\right)$, which locates the double bond in the appropriate arrangement for ring closure 186 and avoids steric clashes between the bulky TMS group and the lactam $\mathbf{8 c}$. In contrast, the attack through the pro- $R$ face of reagent $\mathbf{3}$ (c, Scheme 4) is unfeasible due to the steric hindrance imparted by the TMS group (data not shown).

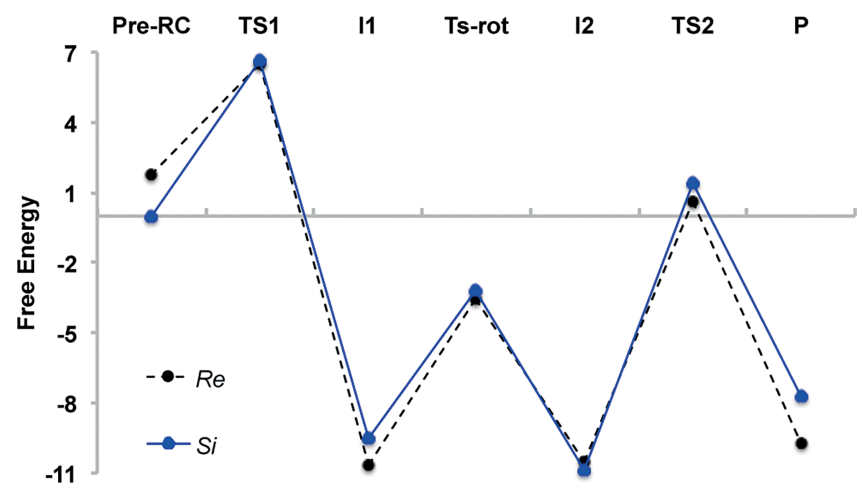

Figure 6. Free energy [kcal/mol] profile for the DBU-catalyzed double Michael addition of the anionic species of Nazarov reagent $\mathbf{4}$ to lactam 8a derived from M062X/6-31G(d) calculations in $\mathrm{CH}_{2} \mathrm{Cl}_{2}$.

\section{Double Michael Additions with Methyl-Substituted Nazarov Reagent 4}

We then examined the annulation reaction between lactam $\mathbf{8 a}$ and Nazarov reagent 4 . It is worth noting that the stereochemical outcome obtained for $3-\mathrm{H} / 15-\mathrm{H}$ and $\mathrm{C}-19 / \mathrm{C}-20$ centers is different depending on the base, $\mathrm{DBU}$ or $\mathrm{Cs}_{2} \mathrm{CO}_{3}$, used to cata- 196 
lyze the reaction (see Scheme 3). As noted above (see Figure 4), the addition reaction was performed considering the attack of the s-trans species of $\mathbf{4}$, which was found to be the predominant form in solution. The annulation reaction was studied

201 through the Re and Si faces of lactam 8a. In contrast to Nazarov reagent 3, the absence of the bulky TMS group permits the attack of $\mathbf{4}$ through both pro- $R$ and pro-S faces (see Scheme 4).

Compared to the reaction of the silylated reagent $\mathbf{3}$, the freeenergy profile for the DBU-promoted attack of reagent 4 to 206 lactam 8a shows distinctive trends (see Figure 6). First, in the most favored approach of the reactants the Nazarov reagent is oriented with the carbonyl oxygen atoms opposite to the sulfonyl group in the lactam, leading to a gauche arrangement for the $\mathrm{C}-\mathrm{H}$ groups that participate in the first Michael addition

211 (H-C...C- $-\mathrm{H}$ dihedral angle 58.1 and $61.6^{\circ}$ in the TSs formed for the Re and Si attacks, respectively; note that this approach was sterically impeded by the bulky TMS unit in the reaction of $\mathbf{3}$ with lactam 8c). This arrangement avoids the repulsion between the lone pairs of the oxygen atoms in the Nazarov rea-

216 gent and the sulfonyl group, whereas it permits the formation of $\mathrm{C}-\mathrm{H} . . . \mathrm{O}$ interactions between the reactants. Indeed, this approach leads to pre-reactant complexes that are more favored (by $3-4 \mathrm{kcal} / \mathrm{mol}$ ) than those obtained for an antiperiplanar approach.

221 The stability of the transition state for the first Michael addition (TS1; Figure 7) is similar for the Re and Si attacks, leading to intermediates (I1) with geometrical features unfeasible for the second addition, because the distance between the reactive $C$ atoms involved in the second Michael addition is close to

$2263.7 \AA$ because of the s-trans arrangement of the Nazarov reagent. In fact, the second Michael addition is preceded by internal rotation of the $\mathbf{4}$ moiety, which involves a small barrier (through a rotational transition state; TS-rot) for the conversion of the s-trans conformation in intermediate $\mathbf{I 1}$ to the s-cis ar-

231 rangement in the novel intermediate $\mathbf{1 2}$. This would facilitate the formation of the second bond, as the distance between the $\mathrm{C}$ atoms is close to $3.1 \AA$. The barriers for the second Michael addition (TS2; Figure 7) through the $R e$ and Si face are 11.1 and $12.3 \mathrm{kcal} / \mathrm{mol}$, respectively. The relative free energy of the

236 transition states $(1.2 \mathrm{kcal} / \mathrm{mol})$ would lead to a ratio of $7.6: 1$ for the Re and Si products, $9 \mathbf{a}$ and $10 \mathrm{a}$, respectively. Finally, between the two cyclized products, the $R e$ annulation is also found to be more stable (by $2.1 \mathrm{kcal} / \mathrm{mol}$ ) than the Si addition, in agreement with the experimental outcome (see Scheme 3).

241 This reactive pathway leads to the experimental stereochemical outcome (see Scheme 3), as noted in the transition state for the second Michael addition (TS2) through the Re face of lactam $\mathbf{8 a}$, which shows the proper orientation of the reactants for the cis $3-\mathrm{H} / 15-\mathrm{H}$ and trans $\mathrm{C} 19-\mathrm{Me} / \mathrm{C} 20-\mathrm{E}\left(\mathrm{SO}_{2} \mathrm{Ph}\right)$ arrange-

246 ments of the final product 9a (Figure 7). The barrier for the cyclization can be ascribed to the formation of a boat-like structure in the forming six-membered ring, which is assisted by a significant pyramidalization (20.6 and $30.5^{\circ}$ ) of the carbon atoms involved in ring closure. On the other hand, the transi-

251 tion state is stabilized by the formation of several $\mathrm{C}-\mathrm{H} \ldots \mathrm{O}$ hydrogen bonds between the sulfonyl oxygen atoms of the lactam and hydrogen atoms of the Nazarov reagent.
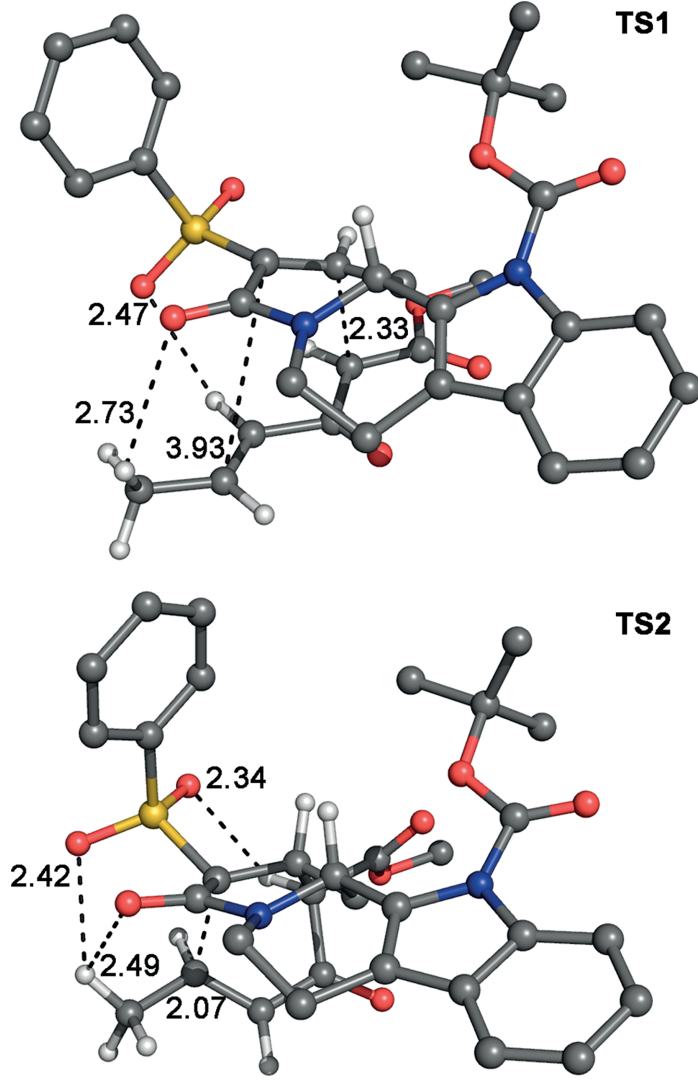

Figure 7. Representation of the transition states (TS1 and TS2) formed in the DBU-catalyzed double Michael additions of the anionic form of Nazarov reagent $\mathbf{4}$ to lactam $\mathbf{8 a}$. The approach occurs through the pro- $R$ face of $\mathbf{4}$ and the $R e$ face of the lactam. For clarity, only selected hydrogen atoms are shown. Complete geometrical data of pre-reactants, transition states, and intermediates are available in the Supporting Information.

As a final remark, the transition state corresponding to the $R e$ attack of reagent $\mathbf{4}$ in the less stable s-cis conformation (Figure S1 in the Supporting Information) to lactam 8a was also 256 identified. Compared with the transition state formed upon attack of the s-trans conformation (TS1 in Figure 7) through the Re face, it was found to be destabilized by $0.6 \mathrm{kcal} / \mathrm{mol}$. This finding, in conjunction with the low population of the $s$-cis conformer ( $<2 \%$; see above), supports the mechanistic pathway 261 shown in Figure 6.

\section{The Effect of the Cesium Cation}

Why does the replacement of $\mathrm{DBU}$ by $\mathrm{Cs}_{2} \mathrm{CO}_{3}$ revert the stereochemical outcome of the reaction with Nazarov reagent 4 ? We hypothesize that the cesium cation plays a dual role in this 266 reaction. First, through coordination to the carbonyl oxygen atoms of 4, the $\mathrm{Cs}^{+}$cation affords the electrostatic stabilization for the generation of the anionic form of the Nazarov reagent (Scheme S1 in the Supporting Information). Second, such electrostatic stabilization suggests that the ionic pair $\mathrm{Cs}^{+}-\mathbf{4}^{-}$can be 271 the reactive species for the addition to lactams $\mathbf{8}$. This assumption is supported by the relatively low permittivity of dichloromethane ( $\varepsilon=8.9$ at room temp.) and by the excess of $\mathrm{Cs}_{2} \mathrm{CO}_{3}$ relative to the Nazarov reagent $\mathbf{4}$, which were used in a 2:1 ratio 
276 under the reaction conditions (see the Experimental Section). On the other hand, although the presence of ionic pairs when $\mathrm{DBU}$ is used cannot be ruled out, delocalization of the positive charge in the amidinium unit and the much larger size of DBU compared with the localized unit charge and smaller size of

281 the $\mathrm{Cs}^{+}$cation (and hence the stronger electrostatic potential) suggests that the presence of ionic pairs should be more relevant for the $\mathrm{Cs}^{+}$cation. Further support comes from both experimental and theoretical evidence about the formation of cesium-coordinated aggregates of diketones and carboxylic 286 acids. ${ }^{[19-21]}$

Under these circumstances, coordination of the $\mathrm{Cs}^{+}$cation to the oxygen atoms of the ester or sulfonyl groups of lactams $\mathbf{8}$ may affect the relative stability of the annulation reaction through the two diastereotopic faces of the lactam. To this end,

291 the attack of the Nazarov reagent 4 should proceed through an antiperiplanar approach between the carbon atoms that will form the first $\mathrm{C}-\mathrm{C}$ bond, because this approach would place the oxygen atoms of both $\mathbf{4}$ and the activating $\mathrm{E}$ group close for coordination to the $\mathrm{Cs}^{+}$cation. To check the feasibility of 296 this mechanistic hypothesis, we determined the free-energy profile for the addition of the $\mathrm{Cs}^{+} . .44$ complex to lactam $\mathbf{8 c}$ (see Scheme 3; note that the benzyl group of $\mathbf{8} \mathbf{b}$ was replaced by a methyl group in the present calculations).

The transition states (TS1) for the first Michael addition be-

301 tween reagent $\mathbf{4}$ and lactam $\mathbf{8 c}$ (Figure 8 ) have similar stabilities, with the Re approach being slightly more favorable (by $0.6 \mathrm{kcal} / \mathrm{mol}$ ). As noted in Figure 9, the $\mathrm{Cs}^{+}$cation is coordinated to the carbonyl oxygen atoms of $\mathbf{4}$ and to the carbonyl oxygen atom of the ester group in lactam $\mathbf{8 b}$, with distances close to $3062.9 \AA$, thus assisting the proper arrangement of the reactants in the annulation reaction. As noted above, this requires the Nazarov reagent $\mathbf{4}$ to be oriented with the carbonyl oxygen atoms pointing toward the molecular edge that contains the ester group in the lactam, so that the attack occurs with a slightly

311 distorted antiperiplanar arrangement of the carbon atoms involved in the first Michael addition ( $\mathrm{H}-\mathrm{C} . . . \mathrm{C}-\mathrm{H}$ dihedral angle -160.7 and $133.5^{\circ}$ for the Re and Si additions, respectively). Figure 9 also shows the asynchronicity of the double Michael addi-

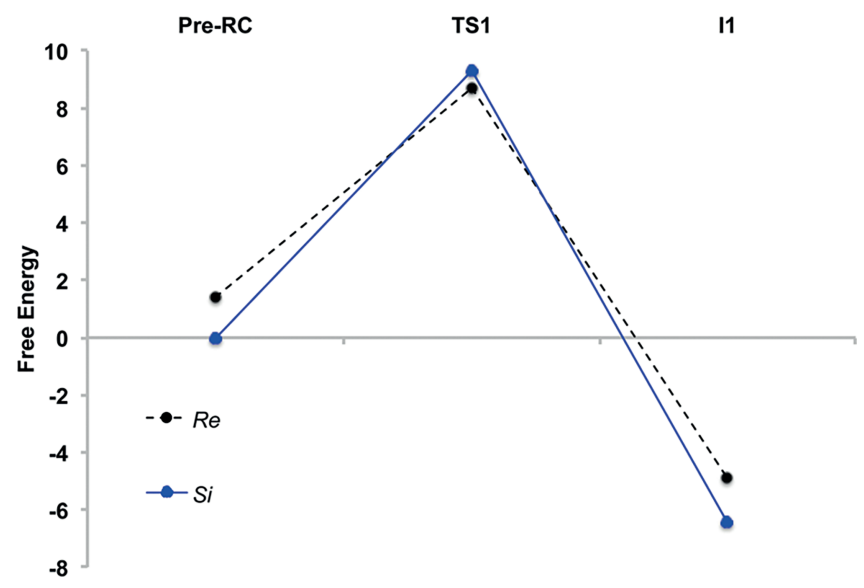

Figure 8. Free energy $[\mathrm{kcal} / \mathrm{mol}]$ profile for the first Michael addition of the $\mathrm{Cs}^{+} \ldots 4$ complex to lactam $\mathbf{8 c}$ derived from M062X/6-31G(d) calculations in $\mathrm{CH}_{2} \mathrm{Cl}_{2}$. tion, because the length of the forming $\mathrm{C}-\mathrm{C}$ bonds is 2.11 (2.16) and 3.43 (3.49) $\AA$ for the $S i(R e)$ addition, thus making necessary 316 the internal rotation to the $4 \mathrm{~s}$-cis conformation required for cyclization, as noted before for the DBU-catalyzed process.
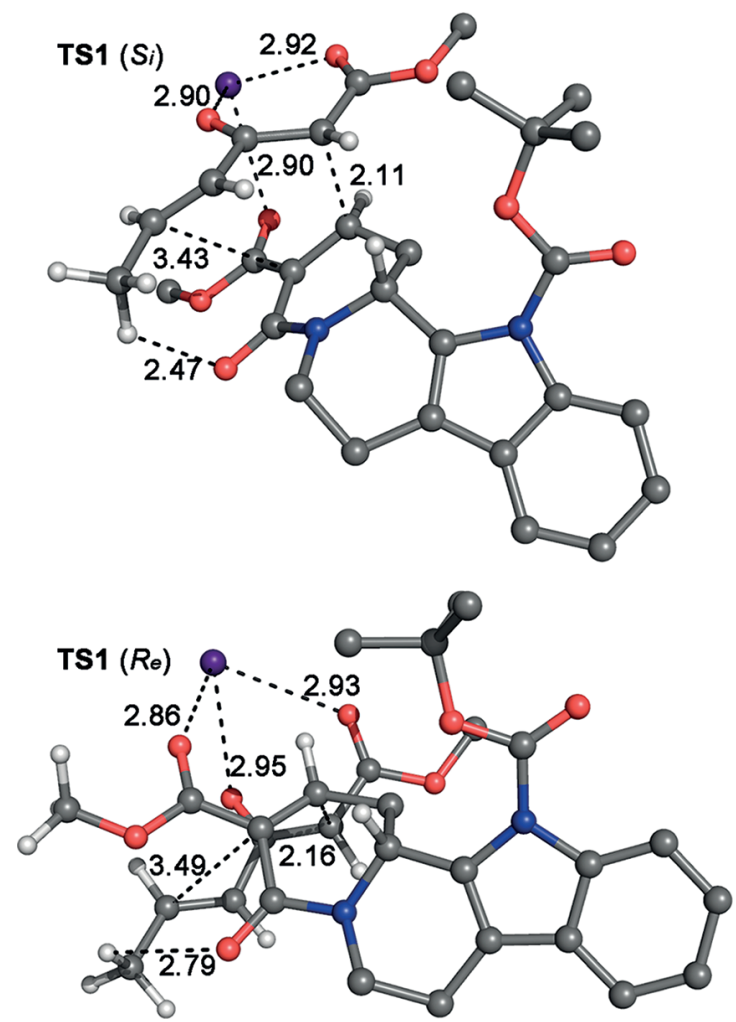

Figure 9. Representation of the transition state (TS1) formed in the first Michael addition of the $\mathrm{Cs}^{+} \ldots 4$ complex to lactam $\mathbf{8 c}$. The approach occurs through the Si (top; pro- $R$ face of 4), and Re (bottom; pro-S face of 4) faces of the lactam. For clarity, only selected hydrogen atoms are shown. The $\mathrm{Cs}^{+}$ cation is shown as a violet sphere. Complete geometrical data of pre-reactants, transition states, and intermediates are available in the Supporting Information.

Whether the $\mathrm{Cs}^{+}$cation remains coordinated along the rest of the cyclization reaction is more questionable, because the formation of the first $\mathrm{C}-\mathrm{C}$ bond in intermediate $\mathbf{I 1}$ is concomi- 321 tant to a charge transfer from the Nazarov reagent to carbon atom C-20 in the lactam. Thus, the Mulliken charge of this latter atom changes from $-0.05 e$ in the pre-reactant (Pre-RC) complex to $-0.18 e$ in I1, whereas the net charge of the oxygen atoms in the Nazarov reagent varies from $-0.63 e$ in Pre-RC to 326 $-0.52 e$ in I1. The charge transfer from 4 to $\mathbf{8 c}$ should weaken the electrostatic stabilization between the Nazarov reagent and the $\mathrm{Cs}^{+}$cation, which is presumably released to the solvent environment. The theoretical computation of the absolute free energy of $\mathrm{Cs}^{+}$coordination is challenging, especially due to the 331 difficulty in estimating the solvation contribution in the complex environment of the reaction. However, this term cancels out when the relative free energy of $\mathrm{Cs}^{+}$release from the prereactant complex (Pre-RC) and the intermediate (I1) is determined, as noted in Scheme 5. Calculations performed for the 336 corresponding species originated through the Re and Si addition of $\mathrm{Cs}^{+} . . .4$ to lactam $\mathbf{8 c}$ indicate that the cation release from 
the intermediate is favored by $4.6 \mathrm{kcal} / \mathrm{mol}$ in the two cases, as expected from the charge transfer from $\mathbf{4}$ to $\mathbf{8 c}$.

$$
\begin{aligned}
& \text { Pre-RC } \quad \mathrm{Cs}^{+\ldots} 4^{-}---8 \mathrm{c} \stackrel{\Delta \mathrm{G}_{\text {Pre-RC }}}{\longrightarrow} \mathrm{Cs}^{+}+4^{----8 c} \\
& \text { I1 } \mathrm{Cs}^{+\ldots 4} 4-8 \mathrm{c}^{-} \stackrel{\Delta \mathrm{G}_{11}}{\longrightarrow} \mathrm{Cs}^{+}+4-8 \mathrm{c}^{-} \\
& \Delta \Delta G=\Delta G_{11}-\Delta G_{\text {Pre }-R C}
\end{aligned}
$$

Scheme 5. Calculation of the relative free energy of $\mathrm{Cs}^{+}$release between the pre-reactant complex and the intermediate formed after the first Michael addition between the anionic species of $\mathbf{4}$ and lactam $\mathbf{8 c}$

341 Based on the preceding discussion, the free-energy profile leading from intermediate $\mathbf{I 1}$ to the ring closure was determined with and without the presence of the coordinated $\mathrm{Cs}^{+}$ cation (Figure 10). The results indicate that the transition state (TS2) for the second Michael addition from the Si face is favored 346 in the two cases: the Re TS2 is destabilized by $1.1 \mathrm{kcal} / \mathrm{mol}$ in the presence of $\mathrm{Cs}^{+}$, increasing up to $2.6 \mathrm{kcal} / \mathrm{mol}$ in the absence of $\mathrm{Cs}^{+}$coordination, which would lead to a stereochemical ratio of 81:1 for the Si and Re cyclized products. Compared with the reaction with the coordinated $\mathrm{Cs}^{+}$cation, this repre-

351 sents a 13 -fold increase in the stereoselectivity of the annulation reaction.
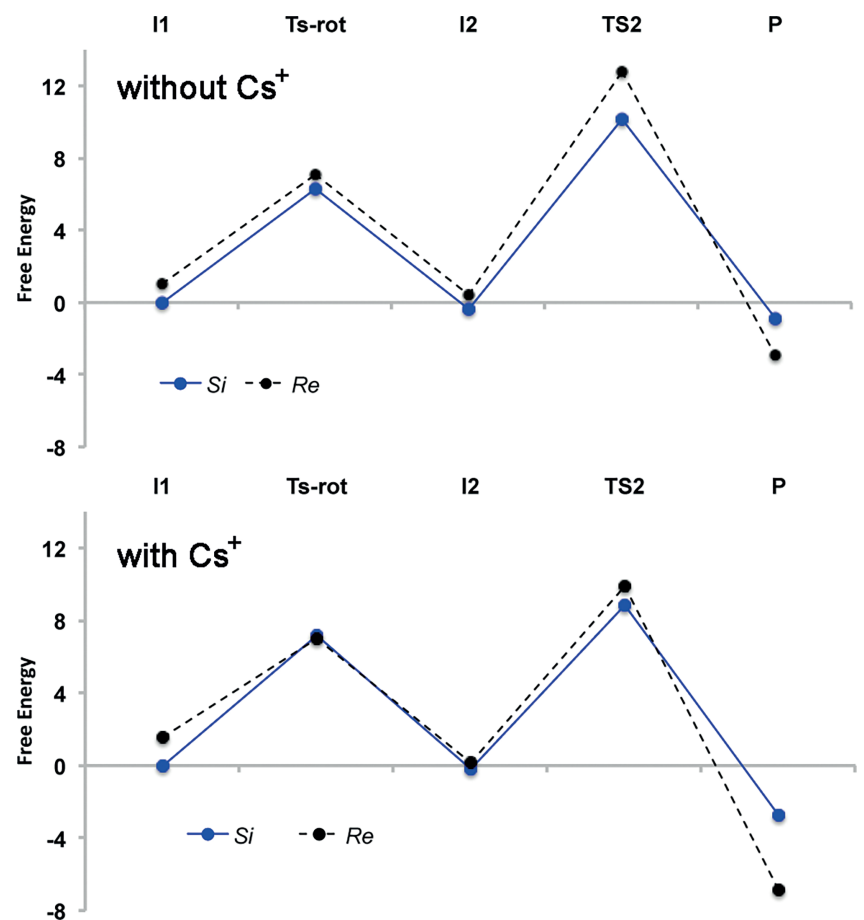

Figure 10. Free energy [ $\mathrm{kcal} / \mathrm{mol}$ ] profile for the second Michael addition of the anionic species of Nazarov reagent $\mathbf{4}$ to lactam $\mathbf{8 c}$ in the absence (top) and presence (bottom) of coordinated $\mathrm{Cs}^{+}$cation derived from M062X/6$31 \mathrm{G}(\mathrm{d})$ calculations in $\mathrm{CH}_{2} \mathrm{Cl}_{2}$.

Inspection of the transition state for the second Michael addition (Figure 11) reveals that the formation of the second $\mathrm{C}-\mathrm{C}$ bond is more advanced in the absence of coordinated $\mathrm{Cs}^{+}$, as 356 noted in the shorter length of the forming bond $(2.08 \AA$ vs. $2.18 \AA$ in the absence and presence of the $\mathrm{Cs}^{+}$cation, respec- tively; see Figure 11), as well as in the larger pyramidalization of the respective carbon atoms (close to $19^{\circ}$ in the absence of the $\mathrm{Cs}^{+}$cation vs. $15^{\circ}$ with the coordinated $\mathrm{Cs}^{+}$cation). Let us note that the addition from the Si face yields the experimental 361 stereochemistry characterized by trans $3-\mathrm{H} / 15-\mathrm{H}$ and cis $\mathrm{C} 19-$ $\mathrm{Me} / \mathrm{C} 2 \mathrm{O}-\mathrm{CO}_{2} \mathrm{Me}$ relationships (Figure 11 ).

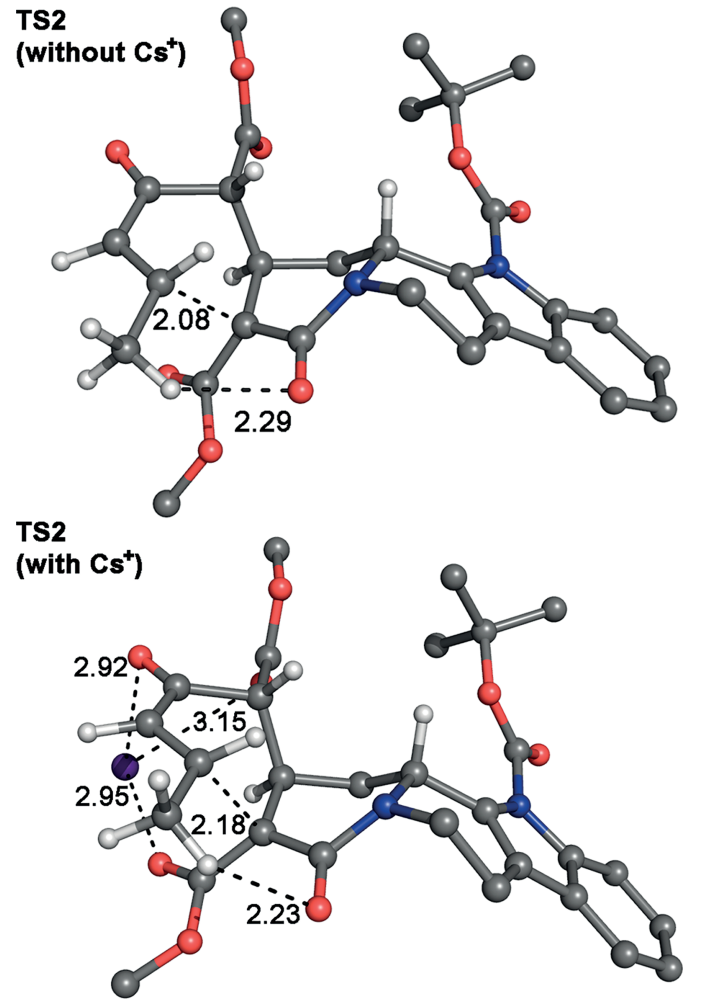

Figure 11. Representation of the transition state (TS2) formed in the second Michael addition of the anionic species of Nazarov reagent $\mathbf{4}$ to lactam $\mathbf{8 c}$ in the absence (top) and presence (bottom) of a coordinated $\mathrm{Cs}^{+}$cation. The approach occurs from the pro- $R$ face of $\mathbf{4}$ and the Si face of the lactam. For clarity, only selected hydrogen atoms are shown. The $\mathrm{Cs}^{+}$cation is shown as a violet sphere. Complete geometrical data of pre-reactants, transition states, and intermediates are available in the Supporting Information.

Overall, the present results suggest that coordination of the $\mathrm{Cs}^{+}$cation to the carbonyl oxygen atoms of both the Nazarov reagent and the activating $\mathrm{E}$ group of the lactam is a key factor 366 in promoting the proper arrangement of $\mathbf{4}$ relative to the lactam. The coordination forces the carbon atoms that participate in the first Michael addition to adopt an antiperiplanar orientation, which, in turn, determines the final stereochemical outcome of the cyclized product.

To further explore the crucial role of cesium in the mechanism of the double Michael addition, the reaction between lactam $\mathbf{8 a}$ and Nazarov reagent $\mathbf{4}$ was performed using $\mathrm{Li}_{2} \mathrm{CO}_{3}$ instead of $\mathrm{Cs}_{2} \mathrm{CO}_{3}$. In this case, the tetracyclic intermediate D (Figure 2; $\mathrm{R}=\mathrm{H}$ ), resulting from the initial Michael addition, 376 was isolated as a $\mathrm{C}-15$ mixture of stereoisomers. An additional treatment $\left(\mathrm{CH}_{2} \mathrm{Cl}_{2}, 20 \mathrm{~h}\right)$ with $\mathrm{Li}_{2} \mathrm{CO}_{3}$ did not lead to any pentacyclic cyclized product.

The different outcome obtained in the presence of $\mathrm{Li}_{2} \mathrm{CO}_{3}$ can be explained by the structural constraints imposed by the 381 smaller ionic radius of $\mathrm{Li}^{+}$, which would perturb the structural 
and energetic features of the $\mathrm{Cs}^{+}$-coordinated reactive complex. Thus, theoretical calculations revealed that the intrinsic stability of the TS (TS1) for the first Michael addition is penalized by 386 around 4 and $7 \mathrm{kcal} / \mathrm{mol}$ upon replacement of the $\mathrm{Cs}^{+}$cation by $\mathrm{K}^{+}$and $\mathrm{Li}^{+}$, respectively. A significant destabilization was also found for the intermediate I1 (data not shown). Overall, these findings point out the relevance of the cation in dictating the final outcome of the annulation process.

\section{Enantioselective Synthesis of 17a-Carbaakuammigine}

To illustrate the synthetic potential of the methodology and the versatility of pentacyclic Nazarov-derived adducts in the synthesis of yohimbine-type targets, we examined the conversion of the enantiopure epiallo derivative $7 a$ into 17a-carbaakuam396 migine (15). Reductive removal of the activating phenylsulfonyl group of $7 \mathrm{a}$ using $\mathrm{Na} / \mathrm{Hg}$ at $-78{ }^{\circ} \mathrm{C}$ was completely stereoselective, with retention of configuration, ${ }^{[22]}$ leading to the D/E cisfused pentacycle 11 in excellent yield (Scheme 6). After chemoselective deprotection of the hydroxy group, the removal of the

401 C- 6 hydroxymethyl substituent of 12 was accomplished in $62 \%$ overall yield by oxidation to a carboxylic acid, followed by tinmediated radical decarbonylation of the corresponding acyl selenide. ${ }^{[23]}$ The resulting enolizable $\beta$-keto ester 13 was then converted into $\alpha, \beta$-unsaturated ester 14 by palladium-catalyzed re406 ductive coupling ${ }^{[24]}$ of the corresponding vinyl triflate. Finally, after deprotection of the indole nitrogen atom, chemoselective alane reduction of the lactam carbonyl group completed the enantioselective synthesis of 17a-carbaakuammigine (15).

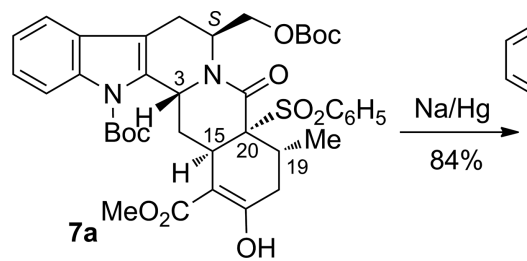<smiles>[R]C[C@H]1Cc2c(n(C(=O)[O-])c3ccccc23)[C@@]2(C)C[C@H]3C(C(=O)OC)=C(O)C[C@H](C)[C@H]3[C@H]1C2=O</smiles>
TFA $\square 11 \mathrm{R}=\mathrm{BOC}$ $92 \% \longrightarrow 12 \mathrm{R}=\mathrm{H}$

(1) DMP, then $\mathrm{NaClO}_{2} \quad 62 \%$

(2) $\left(\mathrm{C}_{6} \mathrm{H}_{5} \mathrm{Se}\right)_{2}, n \mathrm{Bu}_{3} \mathrm{P}$ overall

(3) AIBN, $n \mathrm{Bu}_{3} \mathrm{SnH}$

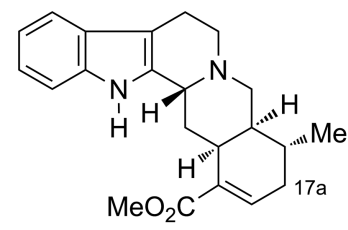

15, 17a-carbaakuammigine

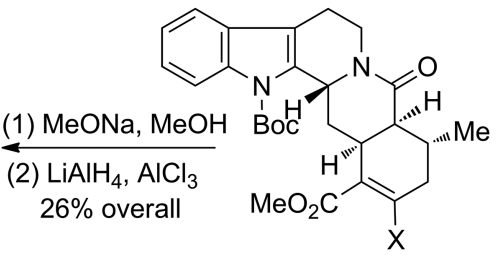

(1) $\mathrm{NaH}, \mathrm{PhNTf}_{2} \quad 13 \mathrm{X}=\mathrm{OH}$

(2) $\mathrm{LiCl}, \mathrm{Pd}\left(\mathrm{PPh}_{3}\right)_{4} \longrightarrow 14 \mathrm{X}=\mathrm{H}$ $\mathrm{BuSnH}$ $60 \%$ overall

Scheme 6. Enantioselective synthesis of 17a-carbaakuammigine.

The cis ring junction of the above pentacyclic derivatives 1141115 was initially deduced by ${ }^{1} \mathrm{H}$ NMR spectroscopic analysis, from the observation of positive NOE effects between $15-\mathrm{H} / 20$ $\mathrm{H}, 15-\mathrm{H} / \mathrm{C} 19-\mathrm{Me}$, and 20-H/C19-Me in $\mathbf{1 1}$ and the triflate derived from 13. Additionally, the $3-\mathrm{H} / 15-\mathrm{H}$ trans stereochemistry in this series was unambiguously confirmed when the NMR spectroscopic data of enantiopure compound $\mathbf{1 3}$ proved to be identi- 416 cal to those of racemic $\mathbf{1 3}$ prepared by dephenylsulfonylation of $\mathbf{1 0 a}$, of known relative configuration (Scheme 7).
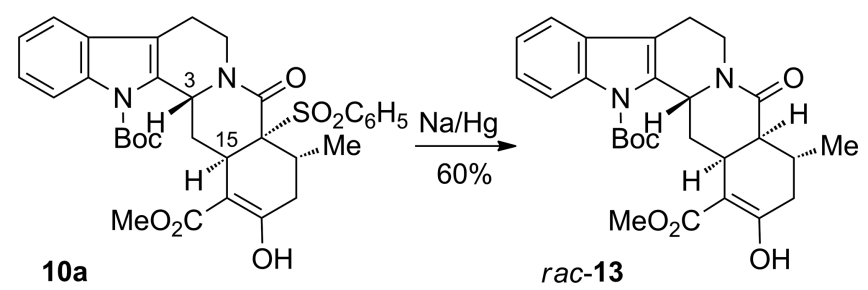

Scheme 7. Confirmation of the relative strereochemistry of $\mathbf{1 3 .}$

\section{Conclusions}

The potential of the annulation reactions performed with different Nazarov-like reagents to accomplish the controlled stereo- 421 selective synthesis of complex heterocyclic compounds is well known, as illustrated here in the synthesis of yohimbine-type adducts. However, the present results highlight the dramatic change of the facial selectivity triggered by the apparently minor change originated upon replacement of $\mathrm{DBU}$ by $\mathrm{Cs}_{2} \mathrm{CO}_{3} 426$ as the base. We propose that this unexpected effect can be related to the coordination of the $\mathrm{Cs}^{+}$cation to the carbonyl oxygen atoms of both the Nazarov reagent and the electronwithdrawing group in the lactam, because this determines the preferred orientation of the reactants, and ultimately the stereo- 431 chemical outcome of the cyclized products. Support for the specific role of the $\mathrm{Cs}^{+}$cation in determining the products of the double Michael addition comes from the very different outcome obtained upon replacement of $\mathrm{Cs}_{2} \mathrm{CO}_{3}$ by $\mathrm{Li}_{2} \mathrm{CO}_{3}$, since no pentacyclic cyclized product was isolated in this latter case. 436 Overall, this study points out that the base can be an effective player for the control of the stereoselective addition, and hence choice of the base may be a crucial factor in dictating the most efficient way to attain the desired cyclized product. These findings open new avenues for the fine regulation of the target 441 product obtained in these chemical reactions.

\section{Experimental Section}

Reaction of Unsaturated Lactams $5 a$ and 8a with Nazarov Reagent 4 Using DBU: A solution of unsaturated lactam $5 a^{[7]}$ or $\mathbf{8} \mathbf{a}^{[8]}$ (1 equiv.) in anhydrous THF was added at $0{ }^{\circ} \mathrm{C}$ under an inert gas 446 to a solution of the Nazarov reagent 4 (2 equiv.) and DBU (1 equiv.) in anhydrous THF $(0.02 \mathrm{M})$, and the mixture was warmed slowly to room temperature. After $20 \mathrm{~h}$ of stirring at room temperature, the reaction was quenched with $\mathrm{H}_{2} \mathrm{O}$, and the mixture was extracted with EtOAc. The combined organic extracts were washed with brine, 451 dried with anhydrous $\mathrm{MgSO}_{4}$, filtered, and concentrated under reduced pressure. Flash chromatography of the resulting residue (9:1, hexane/EtOAc) afforded compounds $\mathbf{6 a}(83 \%)$ or $\mathbf{9 a}(76 \%)$, respectively, as pale-yellow foams.

Compound 6a: $[\alpha]_{D}^{22}=+75.4\left(c=0.86\right.$ in $\left.\mathrm{CHCl}_{3}\right) .{ }^{1} \mathrm{H}$ NMR $(400 \mathrm{MHz}, 456$ $\mathrm{CDCl}_{3}, \mathrm{COSY}, g-\mathrm{HSQC}$, enol form, $25^{\circ} \mathrm{C}$, TMS): $\delta=0.97$ (d, $J=6.8 \mathrm{~Hz}$, 
$\left.3 \mathrm{H}, \mathrm{CH}_{3}\right), 1.43\left[\mathrm{~s}, 9 \mathrm{H},\left(\mathrm{CH}_{3}\right)_{3} \mathrm{C}\right], 1.44$ (masked, $\left.1 \mathrm{H}, 14-\mathrm{H}\right), 1.73[\mathrm{~s}, 9$ $\left.\mathrm{H},\left(\mathrm{CH}_{3}\right)_{3} \mathrm{C}\right], 2.17(\mathrm{dd}, J=18.4,0.8 \mathrm{~Hz}, 1 \mathrm{H}, 18-\mathrm{H}), 2.77$ (ddd, $J=16.8$, 6.0, $2.4 \mathrm{~Hz}, 1 \mathrm{H}, 6-\mathrm{H}), 2.87(\mathrm{dt}, J=16.8,1.6 \mathrm{~Hz}, 1 \mathrm{H}, 6-\mathrm{H}), 3.05(\mathrm{~m}, 1$ $461 \mathrm{H}, 19-\mathrm{H}), 3.14-3.21(\mathrm{~m}, 2 \mathrm{H}, 18-\mathrm{H}, 14-\mathrm{H}), 3.67$ (dd, J= 10.8, $5.2 \mathrm{~Hz}, 1$ $\left.\mathrm{H}, \mathrm{CH}_{2} \mathrm{O}\right), 3.85$ (dd, $\left.J=10.8,8.8 \mathrm{~Hz}, 1 \mathrm{H}, \mathrm{CH}_{2} \mathrm{O}\right), 3.92\left(\mathrm{~s}, 3 \mathrm{H}, \mathrm{CH}_{3} \mathrm{O}\right)$, $3.96(\mathrm{~m}, 1 \mathrm{H}, 15-\mathrm{H}), 5.14(\mathrm{dd}, J=10.4,2.0 \mathrm{~Hz}, 1 \mathrm{H}, 3-\mathrm{H}), 5.49(\mathrm{~m}, 1$ $\mathrm{H}, 5-\mathrm{H}), 7.23\left(\mathrm{td}, J=7.6,1.2 \mathrm{~Hz}, 1 \mathrm{H}, \mathrm{H}_{\mathrm{AR}}\right), 7.29(\mathrm{td}, J=6.8,1.2 \mathrm{~Hz}$, $\left.1 \mathrm{H}, \mathrm{H}_{\mathrm{AR}}\right), 7.40\left(\mathrm{dd}, J=6.8,1.2 \mathrm{~Hz}, 1 \mathrm{H}, \mathrm{H}_{\mathrm{AR}}\right), 7.57(\mathrm{tt}, J=7.6,0.8 \mathrm{~Hz}$, $\left.4662 \mathrm{H}, \mathrm{H}-\mathrm{m} \mathrm{C}_{6} \mathrm{H}_{5}\right), 7.67\left(\mathrm{tt}, J=7.6,1.2 \mathrm{~Hz}, 1 \mathrm{H}, \mathrm{H}-p \mathrm{C}_{6} \mathrm{H}_{5}\right), 7.94(\mathrm{~d}, J=$ $7.6 \mathrm{~Hz}, 1 \mathrm{H}, \mathrm{H}_{\mathrm{AR}}$ ), 8.01 (dd, J = 7.6, $0.8 \mathrm{~Hz}, 2 \mathrm{H}, \mathrm{H}-\mathrm{o} \mathrm{C}_{6} \mathrm{H}_{5}$ ), 12.40 (s, $1 \mathrm{H}, \mathrm{OH})$ ppm. ${ }^{13} \mathrm{C}$ NMR (100.6 MHz, $\left.\mathrm{CDCl}_{3}, 25{ }^{\circ} \mathrm{C}, \mathrm{TMS}\right): \delta=20.8$ $\left(\mathrm{CH}_{3}\right), 22.2(\mathrm{C}-6), 27.7\left[\left(\mathrm{CH}_{3}\right)_{3} \mathrm{C}\right], 28.3\left[\left(\mathrm{CH}_{3}\right)_{3} \mathrm{C}\right], 30.5(\mathrm{C}-19), 31.5(\mathrm{C}-$ 15), 33.1 (C-18), $35.0(\mathrm{C}-14), 45.7(\mathrm{C}-5), 52.1\left(\mathrm{CH}_{3} \mathrm{O}\right), 52.7(\mathrm{C}-3), 64.8$ $471\left(\mathrm{CH}_{2} \mathrm{O}\right), 76.0(\mathrm{C}-20), 82.4\left[\left(\mathrm{CH}_{3}\right)_{3} \mathrm{C}\right], 84.4\left[\left(\mathrm{CH}_{3}\right)_{3} \mathrm{C}\right], 97.3(\mathrm{C}-16), 114.4$ $\left(\mathrm{C}_{\mathrm{AR}}\right), 116.1\left(\mathrm{CH}_{\mathrm{AR}}\right), 118.3\left(\mathrm{CH}_{\mathrm{AR}}\right), 123.1\left(\mathrm{CH}_{\mathrm{AR}}\right), 124.8\left(\mathrm{CH}_{\mathrm{AR}}\right), 128.4$ $\left(2 \mathrm{C}-m \mathrm{C}_{6} \mathrm{H}_{5}\right), 128.8\left(\mathrm{C}_{\mathrm{AR}}\right), 131.1\left(2 \mathrm{C}-\mathrm{o} \mathrm{C}_{6} \mathrm{H}_{5}\right), 133.4\left(\mathrm{C}_{\mathrm{AR}}\right), 134.1(\mathrm{C}-\mathrm{p}$ $\left.\mathrm{C}_{6} \mathrm{H}_{5}\right), 136.6\left(\mathrm{C}_{\mathrm{AR}}\right), 136.7\left(\mathrm{C}_{\mathrm{AR}}\right), 150.1(\mathrm{CO}), 153.0(\mathrm{CO}), 165.7(\mathrm{CO})$, 170.9, 172.1 (C-17, CO) ppm. IR (ATR Pike): $\tilde{v}=1645,1739 \mathrm{~cm}^{-1}(\mathrm{C}=$

476 O). HRMS (ESI): calcd. for $\left[\mathrm{C}_{39} \mathrm{H}_{46} \mathrm{~N}_{2} \mathrm{O}_{11} \mathrm{~S}+\mathrm{Na}\right]^{+} 773.2715$; found 773.2717 .

Compound 9a: ${ }^{1} \mathrm{H}$ NMR (400 MHz, $\mathrm{CDCl}_{3}, \mathrm{COSY}, \mathrm{g}$-HSQC, enol form, $25^{\circ} \mathrm{C}$, TMS): $\delta=0.97\left(\mathrm{~d}, J=6.8 \mathrm{~Hz}, 3 \mathrm{H}, \mathrm{CH}_{3}\right), 1.42$ (masked, $1 \mathrm{H}$, 14-H), $1.72\left[\mathrm{~s}, 9 \mathrm{H},\left(\mathrm{CH}_{3}\right)_{3} \mathrm{C}\right], 2.17(\mathrm{dd}, J=17.6 \mathrm{~Hz}$, $((<=$ AUTHOR: 481 2nd coupling missing; please check!)) $1 \mathrm{H}, 18$ eq- $\mathrm{H}), 2.55-2.68$ (m, $3 \mathrm{H}, 2$ 6-H, 5-H), 3.02-3.17 (m, $3 \mathrm{H}, 18-\mathrm{H}, 14-\mathrm{H}, 19-\mathrm{H}), 3.88$ (m, 1 $\mathrm{H}, 15-\mathrm{H}), 3.92\left(\mathrm{~s}, 3 \mathrm{H}, \mathrm{CH}_{3} \mathrm{O}\right), 4.84(\mathrm{~m}, 1 \mathrm{H}, 5-\mathrm{H}), 5.12(\mathrm{dd}, J=10.0$, $2.4 \mathrm{~Hz}, 1 \mathrm{H}, 3-\mathrm{H}), 7.23\left(\mathrm{td}, J=7.6,1.2 \mathrm{~Hz}, 1 \mathrm{H}, \mathrm{H}_{\mathrm{AR}}\right), 7.28(\mathrm{td}, J=6.8$, $\left.1.2 \mathrm{~Hz}, 1 \mathrm{H}, \mathrm{H}_{\mathrm{AR}}\right), 7.39\left(\mathrm{dd}, J=6.8,1.2 \mathrm{~Hz}, 1 \mathrm{H}, \mathrm{H}_{\mathrm{AR}}\right), 7.56(\mathrm{tt}, J=7.6$, $\left.4860.8 \mathrm{~Hz}, 2 \mathrm{H}, \mathrm{H}-m \mathrm{C}_{6} \mathrm{H}_{5}\right), 7.65\left(\mathrm{tt}, J=7.6,1.2 \mathrm{~Hz}, 1 \mathrm{H}, \mathrm{H}-p \mathrm{C}_{6} \mathrm{H}_{5}\right), 7.91$ $\left(\mathrm{d}, J=7.6 \mathrm{~Hz}, 1 \mathrm{H}, \mathrm{H}_{\mathrm{AR}}\right), 7.99\left(\mathrm{dd}, J=7.6,0.8 \mathrm{~Hz}, 2 \mathrm{H}, \mathrm{H}-\mathrm{o} \mathrm{C}_{6} \mathrm{H}_{5}\right)$, $12.45(\mathrm{~s}, 1 \mathrm{H}, \mathrm{OH}) \mathrm{ppm} .{ }^{13} \mathrm{C}$ NMR $\left(100.6 \mathrm{MHz}, \mathrm{CDCl}_{3}, 25^{\circ} \mathrm{C}, \mathrm{TMS}\right)$ : $\delta=20.9\left(\mathrm{CH}_{3}\right), 21.6(\mathrm{C}-6), 28.3\left[\left(\mathrm{CH}_{3}\right)_{3} \mathrm{C}\right], 30.1(\mathrm{C}-19), 31.5(\mathrm{C}-15)$, $33.1(\mathrm{C}-18), 34.6(\mathrm{C}-14), 40.3(\mathrm{C}-5), 52.1\left(\mathrm{CH}_{3} \mathrm{O}\right), 55.3(\mathrm{C}-3), 75.8(\mathrm{C}-$ $49120), 84.3\left[\left(\mathrm{CH}_{3}\right)_{3} \mathrm{C}\right], 97.3(\mathrm{C}-16), 115.9\left(\mathrm{CH}_{\mathrm{AR}}\right), 118.3\left(\mathrm{CH}_{\mathrm{AR}}\right), 118.4$ $\left(\mathrm{C}_{\mathrm{AR}}\right), 123.1\left(\mathrm{CH}_{\mathrm{AR}}\right), 124.7\left(\mathrm{CH}_{\mathrm{AR}}\right), 128.4\left(2 \mathrm{C}-m \mathrm{C}_{6} \mathrm{H}_{5}\right), 128.6\left(\mathrm{C}_{\mathrm{AR}}\right)$, $130.9\left(2{\mathrm{C}-o ~ C_{6}} \mathrm{H}_{5}\right), 134.0\left(\mathrm{C}-p \mathrm{C}_{6} \mathrm{H}_{5}\right), 134.9\left(\mathrm{C}_{\mathrm{AR}}\right), 136.3\left(\mathrm{C}_{\mathrm{AR}}\right), 136.7$ $\left(C_{A R}\right), 150.2(C O), 165.2(C O), 170.9,172.0(C-17, C O)$ ppm. IR (ATR Pike): $\tilde{v}=1648,1731 \mathrm{~cm}^{-1} \quad(\mathrm{C}=\mathrm{O})$. HRMS (ESI): calcd. for $496\left[\mathrm{C}_{33} \mathrm{H}_{36} \mathrm{~N}_{2} \mathrm{O}_{8} \mathrm{~S}+\mathrm{H}\right]^{+}$621.2265; found: 621.2272 .

Reaction of Unsaturated Lactams 5 and 8 with Nazarov Reagent 4 Using $\mathrm{Cs}_{\mathbf{2}} \mathrm{CO}_{3}$ : A solution of unsaturated lactam $\mathbf{5} \mathbf{a}^{[7]} \mathbf{5} \mathbf{b}^{[7]} \mathbf{8 a}^{[8]}$ or $\mathbf{8} \mathbf{b}^{[7]}$ (1 equiv.) in anhydrous $\mathrm{CH}_{2} \mathrm{Cl}_{2}(0.02-0.005 \mathrm{M}$ ) was added at $0{ }^{\circ} \mathrm{C}$ under an inert gas to a solution of the Nazarov reagent 4

501 (3 equiv.) and $\mathrm{Cs}_{2} \mathrm{CO}_{3}$ (6 equiv.) in anhydrous $\mathrm{CH}_{2} \mathrm{Cl}_{2}$, and the mixture was warmed slowly to room temperature. After $20 \mathrm{~h}$ of stirring at room temperature, the mixture was concentrated under reduced pressure. Flash chromatography (9:1, hexane/EtOAc) of the resulting oil afforded compounds 7a (86\%), 7b (87\%), 10a (88\%) or 10b 506 (59\%), respectively, as pale-yellow foams.

Compound 7a: Obtained in 9:1 enol/keto ratio; m.p. 98-100 ${ }^{\circ} \mathrm{C}$; $[\alpha]_{\mathrm{D}}^{22}=+20.5\left(c=0.7\right.$ in $\left.\mathrm{CHCl}_{3}\right) .{ }^{1} \mathrm{H}$ NMR $\left(400 \mathrm{MHz}, \mathrm{CDCl}_{3}, \mathrm{COSY}, g-\right.$ HSQC, enol form, $25^{\circ} \mathrm{C}$, TMS): $\delta=1.20\left(\mathrm{~d}, J=6.4 \mathrm{~Hz}, 3 \mathrm{H}, \mathrm{CH}_{3}\right), 1.41$ $\left[\mathrm{s}, 9 \mathrm{H},\left(\mathrm{CH}_{3}\right)_{3} \mathrm{C}\right], 1.69\left[\mathrm{~s}, 9 \mathrm{H},\left(\mathrm{CH}_{3}\right)_{3} \mathrm{C}\right], 1.95(\mathrm{dd}, J=18.0,1.6 \mathrm{~Hz}, 1$ $511 \mathrm{H}, 18-\mathrm{H}), 2.25$ (ddd, $J=14.0,12.0,3.2 \mathrm{~Hz}, 1 \mathrm{H}, 14-\mathrm{H}), 2.56(\mathrm{~d}, J=$ $16.4 \mathrm{~Hz}, 1 \mathrm{H}, 6-\mathrm{H}), 2.69$ (ddd, $J=16.4,4.4,2.4 \mathrm{~Hz}, 1 \mathrm{H}, 6-\mathrm{H}), 2.81$ (m, $2 \mathrm{H}, 18-\mathrm{H}, 19-\mathrm{H}), 3.16$ (app dt, $\mathbf{\square}((<=$ AUTHOR: OK?)) $\square \mathrm{J}=14.0$, 3.2, $3.2 \mathrm{~Hz}, 1 \mathrm{H}, 14-\mathrm{H}), 3.80\left(\mathrm{~m}, 1 \mathrm{H}, \mathrm{CH}_{2} \mathrm{O}\right), 3.81\left(\mathrm{~s}, 3 \mathrm{H}, \mathrm{CH}_{3} \mathrm{O}\right), 4.08$ $\left(\mathrm{m}, 2 \mathrm{H}, 15-\mathrm{H}, \mathrm{CH}_{2} \mathrm{O}\right), 4.94(\mathrm{~d}, J=11.2 \mathrm{~Hz}, 1 \mathrm{H}, 3-\mathrm{H}), 5.63-5.71(\mathrm{~m}, 1$

$516 \mathrm{H}, 5-\mathrm{H}), 7.20-7.60\left(\mathrm{~m}, 6 \mathrm{H}, \mathrm{H}_{\mathrm{AR}}\right), 7.87\left(\mathrm{dd}, J=8.0,1.2 \mathrm{~Hz}, 1 \mathrm{H}, \mathrm{H}_{\mathrm{AR}}\right.$ ), $8.00\left(\mathrm{dd}, J=8.0,1.2 \mathrm{~Hz}, 2 \mathrm{H}, \mathrm{H}_{\mathrm{AR}}\right), 12.2(\mathrm{~s}, 1 \mathrm{H}, \mathrm{OH}) \mathrm{ppm} .{ }^{13} \mathrm{C}$ NMR (100.6 MHz, CDCl $\left.3,25{ }^{\circ} \mathrm{C}, \mathrm{TMS}\right): \delta=14.1\left(\mathrm{CH}_{3}\right), 21.8(\mathrm{C}-6), 27.6$ $\left[\left(\mathrm{CH}_{3}\right)_{3} \mathrm{C}\right], 28.3\left[\left(\mathrm{CH}_{3}\right)_{3} \mathrm{C}\right], 28.7(\mathrm{C}-15), 29.3(\mathrm{C}-14), 31.6(\mathrm{C}-19), 35.2(\mathrm{C}-$
18), $45.6(\mathrm{C}-5), 49.3(\mathrm{C}-3), 52.0\left(\mathrm{CH}_{3} \mathrm{O}\right), 64.3\left(\mathrm{CH}_{2} \mathrm{O}\right), 70.0(\mathrm{C}-20), 82.3$ $\left[\left(\mathrm{CH}_{3}\right)_{3} \mathrm{C}\right], 84.3\left[\left(\mathrm{CH}_{3}\right)_{3} \mathrm{C}\right], 96.7(\mathrm{C}-16), 114.9\left(\mathrm{C}_{\mathrm{AR}}\right), 116.0\left(\mathrm{CH}_{\mathrm{AR}}\right), 118.1521$ $\left(\mathrm{CH}_{\mathrm{AR}}\right), 123.0\left(\mathrm{CH}_{\mathrm{AR}}\right), 124.6\left(\mathrm{CH}_{\mathrm{AR}}\right), 128.2,131.2\left(\mathrm{C}-0, m \mathrm{C}_{6} \mathrm{H}_{5}\right), 128.8$ $\left(\mathrm{C}_{\mathrm{AR}}\right), 133.6,133.7\left(\mathrm{C}_{\mathrm{AR}}, \mathrm{C}-p \mathrm{C}_{6} \mathrm{H}_{5}\right), 136.5\left(\mathrm{C}_{\mathrm{AR}}\right), 138.7\left(\mathrm{C}-i \mathrm{C}_{6} \mathrm{H}_{5}\right), 150.1$ (CO), 153.1 (CO), 166.4 (CO), 171.6 (C-17, CO) ppm. IR (film): $\tilde{v}=$ 1728, $1640 \mathrm{~cm}^{-1}$ (C=O). HRMS (ESI): calcd. for $\left[\mathrm{C}_{39} \mathrm{H}_{46} \mathrm{~N}_{2} \mathrm{O}_{11} \mathrm{~S}+\mathrm{H}\right]^{+}$: 751.2895; found: 751.2892. $\mathrm{C}_{39} \mathrm{H}_{46} \mathrm{~N}_{2} \mathrm{O}_{11} \mathrm{~S}$ (750.86): calcd. C 62.38, H 526 6.17, N 3.73; found C 62.15, H 6.34, N 3.36 .

Compound 7b: Obtained in >9:1 enol/keto ratio. ${ }^{1} \mathrm{H}$ NMR $(400 \mathrm{MHz}$, $\mathrm{CDCl}_{3}, \mathrm{COSY}, g$-HSQC, enol form, $25^{\circ} \mathrm{C}$, TMS): $\delta=1.26$ (d, $J=11.2 \mathrm{~Hz}$, $\left.3 \mathrm{H}, \mathrm{CH}_{3}\right), 1.45\left[\mathrm{~s}, 9 \mathrm{H},\left(\mathrm{CH}_{3}\right)_{3} \mathrm{C}\right], 1.68\left[\mathrm{~s}, 9 \mathrm{H},\left(\mathrm{CH}_{3}\right)_{3} \mathrm{C}\right], 2.01(\mathrm{~m}, 1 \mathrm{H}$, 14-H), 2.10 (masked, $1 \mathrm{H}, 14-\mathrm{H}), 2.40(\mathrm{~m}, 1 \mathrm{H}, 19-\mathrm{H}), 2.65(\mathrm{~d}, J=531$ $16.4 \mathrm{~Hz}, 1 \mathrm{H}, 6-\mathrm{H}), 2.68-2.79(\mathrm{~m}, 2 \mathrm{H}, 18-\mathrm{H}), 2.76-2.90$ (ddd, $J=16.4$, 6.4, $2.4 \mathrm{~Hz}, 1 \mathrm{H}, 6-\mathrm{H}), 3.49(\mathrm{~m}, 1 \mathrm{H}, 15-\mathrm{H}), 3.83\left(\mathrm{~s}, 3 \mathrm{H}, \mathrm{CH}_{3} \mathrm{O}\right), 3.96$ $\left(\mathrm{t}, J=10.4 \mathrm{~Hz}, 1 \mathrm{H}, \mathrm{CH}_{2} \mathrm{O}\right), 4.11\left(\mathrm{dd}, J=10.4,7.2 \mathrm{~Hz}, 1 \mathrm{H}, \mathrm{CH}_{2} \mathrm{O}\right)$, $4.94(\mathrm{dm}, J=8.4 \mathrm{~Hz}, 1 \mathrm{H}, 3-\mathrm{H}), 5.11\left(\mathrm{~d}, J=12.4 \mathrm{~Hz}, 1 \mathrm{H}, \mathrm{CH}_{2} \mathrm{C}_{6} \mathrm{H}_{5}\right)$, $5.17\left(\mathrm{~d}, J=12.4 \mathrm{~Hz}, 1 \mathrm{H}, \mathrm{CH}_{2} \mathrm{C}_{6} \mathrm{H}_{5}\right), 5.74(\mathrm{~m}, 1 \mathrm{H}, 5-\mathrm{H}), 7.19-7.36(\mathrm{~m}, 536$ $\left.7 \mathrm{H}, \mathrm{H}_{\mathrm{AR}}\right), 7.39\left(\mathrm{~d}, J=7.6,1.2 \mathrm{~Hz}, 1 \mathrm{H}, \mathrm{H}_{\mathrm{AR}}\right), 7.94(\mathrm{~d}, J=7.6,1.2 \mathrm{~Hz}$, $\left.1 \mathrm{H}, \mathrm{H}_{\mathrm{AR}}\right), 12.2(\mathrm{~s}, 1 \mathrm{H}, \mathrm{OH}) \mathrm{ppm} .{ }^{13} \mathrm{C} \mathrm{NMR}\left(100.6 \mathrm{MHz}, \mathrm{CDCl}_{3}, 25^{\circ} \mathrm{C}\right.$, TMS): $\delta=14.1\left(\mathrm{CH}_{3}\right), 22.0(\mathrm{C}-6), 27.6\left[\left(\mathrm{CH}_{3}\right)_{3} \mathrm{C}\right], 28.2\left[\left(\mathrm{CH}_{3}\right)_{3} \mathrm{C}\right], 30.4$ (C-19), 31.8 (C-15), $34.0(\mathrm{C}-14, \mathrm{C}-18), 45.6(\mathrm{C}-5), 49.0(\mathrm{C}-3), 51.8$ $\left(\mathrm{CH}_{3} \mathrm{O}\right), 57.8(\mathrm{C}-20), 64.4\left(\mathrm{CH}_{2} \mathrm{O}\right), 67.0\left(\mathrm{CH}_{2} \mathrm{C}_{6} \mathrm{H}_{5}\right), 82.2\left[\left(\mathrm{CH}_{3}\right)_{3} \mathrm{C}\right], 84.0541$ $\left[\left(\mathrm{CH}_{3}\right)_{3} \mathrm{C}\right], 97.0(\mathrm{C}-16), 114.9\left(\mathrm{C}_{\mathrm{AR}}\right), 115.8\left(\mathrm{CH}_{\mathrm{AR}}\right), 118.1\left(\mathrm{CH}_{\mathrm{AR}}\right), 122.9$ $\left(\mathrm{CH}_{\mathrm{AR}}\right), 124.5\left(\mathrm{CH}_{\mathrm{AR}}\right), 127.7-128.8\left(\mathrm{C}_{\mathrm{AR}}, \mathrm{C}-0, m, p \mathrm{C}_{6} \mathrm{H}_{5}\right), 134.4\left(\mathrm{C}_{\mathrm{AR}}\right)$, $135.6\left(\mathrm{C}-i \mathrm{C}_{6} \mathrm{H}_{5}\right), 136.6\left(\mathrm{C}_{\mathrm{AR}}\right), 149.9(\mathrm{CO}), 153.1(\mathrm{CO}), 168.3-172.1$ (C17, 3 CO) ppm. IR (film): $\tilde{v}=1728,1646 \mathrm{~cm}^{-1}(\mathrm{C}=0)$. HRMS (ESI): calcd. for $\left[\mathrm{C}_{41} \mathrm{H}_{48} \mathrm{~N}_{2} \mathrm{O}_{11}+\mathrm{H}\right]^{+} 745.3331$; found 745.3322 .

Compound 10a: ${ }^{1} \mathrm{H}$ NMR (400 MHz, $\mathrm{CDCl}_{3}, \mathrm{COSY}, g$-HSQC, enol form, $25^{\circ} \mathrm{C}$, TMS): $\delta=1.18\left(\mathrm{~d}, J=6.8 \mathrm{~Hz}, 3 \mathrm{H}, \mathrm{CH}_{3}\right), 1.69[\mathrm{~s}, 9 \mathrm{H}$, $\left.\left(\mathrm{CH}_{3}\right)_{3} \mathrm{C}\right], 2.00$ (dd, $\left.J=18.4,2.0 \mathrm{~Hz}, 1 \mathrm{H}, 18-\mathrm{H}\right), 2.27$ (ddd, $J=14.4$, 11.6, $2.6 \mathrm{~Hz}, 1 \mathrm{H}, 14-\mathrm{H}), 2.48-2.61(\mathrm{~m}, 3 \mathrm{H}, 2 \mathrm{6}-\mathrm{H}, 18-\mathrm{H}), 2.74(\mathrm{~m}, 2$ $\mathrm{H}, 19-\mathrm{H}, 5-\mathrm{H}), 3.25(\mathrm{dt}, J=14.4,4.0 \mathrm{~Hz}, 1 \mathrm{H}, 14-\mathrm{H}), 3.93(\mathrm{~s}, 3 \mathrm{H}, 551$ $\left.\mathrm{CH}_{3} \mathrm{O}\right), 3.99$ (br. s, $\left.1 \mathrm{H}, 15-\mathrm{H}\right), 4.99(\mathrm{~m}, 2 \mathrm{H}, 3-\mathrm{H}, 5-\mathrm{H}), 7.21-7.29(\mathrm{~m}$, $\left.2 \mathrm{H}, \mathrm{H}_{\mathrm{AR}}\right), 7.37-7.42\left(\mathrm{~m}, 3 \mathrm{H}, \mathrm{H}_{\mathrm{AR}}\right), 7.53\left(\mathrm{tt}, J=8.0,1.2 \mathrm{~Hz}, 1 \mathrm{H}, \mathrm{H}_{\mathrm{AR}}\right)$, $7.89\left(\mathrm{dd}, J=8.0,1.2 \mathrm{~Hz}, 1 \mathrm{H}, \mathrm{H}_{\mathrm{AR}}\right), 8.00(\mathrm{dd}, J=8.0,1.2 \mathrm{~Hz}, 2 \mathrm{H}$, $\left.\mathrm{H}_{\mathrm{AR}}\right), 12.40(\mathrm{~s}, 1 \mathrm{H}, \mathrm{OH}) \mathrm{ppm} .{ }^{13} \mathrm{C}$ NMR $\left(100.6 \mathrm{MHz}, \mathrm{CDCl}_{3}, 25{ }^{\circ} \mathrm{C}\right.$, TMS): $\delta=14.1\left(\mathrm{CH}_{3}\right), 21.4(\mathrm{C}-6), 28.3\left[\left(\mathrm{CH}_{3}\right)_{3} \mathrm{C}\right], 28.5,28.6(\mathrm{C}-15, \mathrm{C}-556$ 14), 31.1 (C-19), 35.3 (C-18), 40.6 (C-5), $52.1\left(\mathrm{CH}_{3} \mathrm{O}\right), 53.1(\mathrm{C}-3), 76.2$ $(\mathrm{C}-20), 84.4\left[\left(\mathrm{CH}_{3}\right)_{3} \mathrm{C}\right], 97.0(\mathrm{C}-16), 115.8\left(\mathrm{C}_{\mathrm{AR}}\right), 118.2\left(\mathrm{CH}_{\mathrm{AR}}\right), 118.9$ $\left(\mathrm{CH}_{\mathrm{AR}}\right), 122.9\left(\mathrm{CH}_{\mathrm{AR}}\right), 124.4\left(\mathrm{CH}_{\mathrm{AR}}\right), 128.2,131.1\left(\mathrm{C}-0, \mathrm{~m} \mathrm{C}_{6} \mathrm{H}_{5}\right), 128.9$ $\left(\mathrm{C}_{\mathrm{AR}}\right), 133.7\left(\mathrm{C}-p \mathrm{C}_{6} \mathrm{H}_{5}\right), 135.1\left(\mathrm{C}_{\mathrm{AR}}\right), 136.3\left(\mathrm{C}_{\mathrm{AR}}\right), 138.6\left(\mathrm{C}-i \mathrm{C}_{6} \mathrm{H}_{5}\right)$, 150.3 (CO), 165.1 (CO), 170.9 (C-17), 171.9 (CO) ppm.

Compound 10b: ${ }^{1} \mathrm{H}$ NMR (400 MHz, $\mathrm{CDCl}_{3}, \mathrm{COSY}, g$-HSQC, enol form, $25^{\circ} \mathrm{C}, \mathrm{TMS}$ ): $\delta=1.18$ (br. s, $\left.3 \mathrm{H}, \mathrm{CH}_{3}\right), 1.67\left[\mathrm{~s}, 10 \mathrm{H},\left(\mathrm{CH}_{3}\right)_{3} \mathrm{C}\right.$, 14-H], 2.00-2.40 (m, $2 \mathrm{H}, 14-\mathrm{H}, 19-\mathrm{H}), 2.45-2.90(\mathrm{~m}, 5 \mathrm{H}, 2$ 6- H, 5-H, 2 18-H), 3.38 (br. s, $1 \mathrm{H}, 15-\mathrm{H}), 3.82\left(\mathrm{~s}, 3 \mathrm{H}, \mathrm{CH}_{3} \mathrm{O}\right), 4.97-6.05(\mathrm{~m}, 2$ $\mathrm{H}, 5-\mathrm{H}, 3-\mathrm{H}), 5.07\left(\mathrm{~d}, J=12.8 \mathrm{~Hz}, 1 \mathrm{H}, \mathrm{CH}_{2} \mathrm{C}_{6} \mathrm{H}_{5}\right), 5.13(\mathrm{~d}, J=12.8 \mathrm{~Hz}, 566$ $\left.1 \mathrm{H}, \mathrm{CH}_{2} \mathrm{C}_{6} \mathrm{H}_{5}\right), 7.12-7.31\left(3 \mathrm{~m}, 7 \mathrm{H}, \mathrm{H}_{\mathrm{AR}}\right), 7.40(\mathrm{~d}, J=7.6 \mathrm{~Hz}, 1 \mathrm{H}$, $\left.\mathrm{H}_{\mathrm{AR}}\right), 7.95\left(\mathrm{~d}, J=7.6 \mathrm{~Hz}, 1 \mathrm{H}, \mathrm{H}_{\mathrm{AR}}\right)$ ppm. ${ }^{13} \mathrm{C} \mathrm{NMR}\left(100.6 \mathrm{MHz}_{1} \mathrm{CDCl}_{3}\right.$, $\left.25{ }^{\circ} \mathrm{C}, \mathrm{TMS}\right): \delta=15.1\left(\mathrm{CH}_{3}\right), 21.6(\mathrm{C}-6), 28.2\left[\left(\mathrm{CH}_{3}\right)_{3} \mathrm{C}\right], 30.3(\mathrm{C}-19)$, 31.5 (C-15), 34.2, $34.9(\mathrm{C}-14, \mathrm{C}-18), 42.5(\mathrm{C}-5), 51.9\left(\mathrm{CH}_{3} \mathrm{O}\right), 53.6(\mathrm{C}-$ 3), $57.4(\mathrm{C}-20), 66.8\left(\mathrm{CH}_{2} \mathrm{C}_{6} \mathrm{H}_{5}\right), 84.0\left[\left(\mathrm{CH}_{3}\right)_{3} \mathrm{C}\right], 97.2(\mathrm{C}-16), 115.6571$ $\left(\mathrm{CH}_{\mathrm{AR}}\right), 116.0\left(\mathrm{C}_{\mathrm{AR}}\right), 118.2\left(\mathrm{CH}_{\mathrm{AR}}\right), 122.9\left(\mathrm{CH}_{\mathrm{AR}}\right), 124.4\left(\mathrm{CH}_{\mathrm{AR}}\right), 127.6-$ $128.3\left(C_{A R}, C-0, m, p C_{6} H_{5}\right), 135.6\left(C_{A R}, C-i C_{6} H_{5}\right), 136.6\left(C_{A R}\right), 150.2$ (CO), 168.1-172.1 (C-17, 3 CO) ppm. IR (ATR Pike): $\tilde{v}=1652$, $1728 \mathrm{~cm}^{-1}(\mathrm{C}=\mathrm{O})$. HRMS (ESI): calcd. for $\left[\mathrm{C}_{35} \mathrm{H}_{38} \mathrm{~N}_{2} \mathrm{O}_{8}+\mathrm{H}\right]^{+} 615.2701$; found 615.2701 .

When the reaction from $\mathbf{5 a}$ was carried out at $0{ }^{\circ} \mathrm{C}$ for $2 \mathrm{~h}$, intermediate $\mathbf{D}$ was isolated (23\%) by flash chromatography (9:1, hexane/ EtOAc).

Major Isomer: ${ }^{1} \mathrm{H}$ NMR $\left(400 \mathrm{MHz}, \mathrm{CDCl}_{3}, \mathrm{COSY}, \mathrm{g}\right.$-HSQC, $25^{\circ} \mathrm{C}$, TMS): $\delta=1.42\left[\mathrm{~s}, 9 \mathrm{H},\left(\mathrm{CH}_{3}\right)_{3}\right], 1.73\left[\mathrm{~s}, 9 \mathrm{H},\left(\mathrm{CH}_{3}\right)_{3}\right], 1.74(\mathrm{~m}, 1 \mathrm{H}, 1-\mathrm{H}), 1.94581$ 
(ddd, $\left.J=11.6,7.2,1.6 \mathrm{~Hz}, 3 \mathrm{H}, \mathrm{CH}_{3}\right), 2.54(\mathrm{~m}, 1 \mathrm{H}, 1-\mathrm{H}), 2.91(\mathrm{~m}, 2$ $\mathrm{H}, 7-\mathrm{H}), 3.61(\mathrm{~m}, 1 \mathrm{H}, 2-\mathrm{H}), 3.72\left(\mathrm{~s}, 3 \mathrm{H}, \mathrm{CH}_{3} \mathrm{O}\right), 3.94(\mathrm{tt}, J=10.8$, $3.6 \mathrm{~Hz}, 1 \mathrm{H}, \mathrm{CH}_{2} \mathrm{O}$ ), 4.17 (ddd, $J=10.8,6.4,5.6 \mathrm{~Hz}, 1 \mathrm{H}, \mathrm{CH}_{2} \mathrm{O}$ ), 4.27 $(\mathrm{d}, J=4.0 \mathrm{~Hz}, 1 \mathrm{H}, 3-\mathrm{H}), 4.32(\mathrm{~d}, J=6.0 \mathrm{~Hz}, 1 \mathrm{H}, \mathrm{CHCOO}), 5.34-5.44$ $586(\mathrm{~m}, 2 \mathrm{H}, 6-\mathrm{H}, 12-\mathrm{Hb}), 6.20-6.28(\mathrm{~m}, 1 \mathrm{H}, \mathrm{CH}=), 7.07-7.14(\mathrm{dq}, J=$ $15.8,6.8 \mathrm{~Hz}, 1 \mathrm{H}, \mathrm{CH}=), 7.23-7.33\left(2 \mathrm{~m}, 2 \mathrm{H}, \mathrm{H}_{\mathrm{AR}}\right), 7.41(\mathrm{dm}, J=8.0 \mathrm{~Hz}$, $\left.1 \mathrm{H}, \mathrm{H}_{\mathrm{AR}}\right), 7.57\left(\mathrm{~m}, 2 \mathrm{H}, \mathrm{H}_{\mathrm{AR}}\right), 7.68\left(\mathrm{~m}, 1 \mathrm{H}, \mathrm{H}_{\mathrm{AR}}\right), 7.99\left(\mathrm{~m}, 2 \mathrm{H}, \mathrm{H}_{\mathrm{AR}}\right)$, $8.11\left(\mathrm{~d}, J=8.0 \mathrm{~Hz}, 1 \mathrm{H}, \mathrm{H}_{\mathrm{AR}}\right)$ ppm. ${ }^{13} \mathrm{C} \mathrm{NMR}\left(100.6 \mathrm{MHz} \mathrm{CDCl}_{3}\right.$, $\left.25^{\circ} \mathrm{C}, \mathrm{TMS}\right): \delta=18.6\left(\mathrm{CH}_{3}\right), 21.7(\mathrm{C}-7), 27.7\left[\left(\mathrm{CH}_{3}\right)_{3} \mathrm{C}\right], 28.2\left[\left(\mathrm{CH}_{3}\right)_{3} \mathrm{C}\right]$,

$59131.6(\mathrm{C}-2), 34.2(\mathrm{C}-1), 45.6,51.0(\mathrm{C}-6, \mathrm{C}-12 \mathrm{~b}), 52.6\left(\mathrm{CH}_{3} \mathrm{O}\right), 58.4(\mathrm{C}-3)$, $65.6\left(\mathrm{CH}_{2} \mathrm{O}\right), 70.1(\mathrm{CHCOO}), 82.3\left[\left(\mathrm{CH}_{3}\right)_{3} \mathrm{C}\right], 84.9\left[\left(\mathrm{CH}_{3}\right)_{3} \mathrm{C}\right], 113.6\left(\mathrm{C}_{\mathrm{AR}}\right)$, $115.9\left(\mathrm{C}_{\mathrm{AR}}\right), 118.1\left(\mathrm{CH}_{\mathrm{AR}}\right), 122.9\left(\mathrm{CH}_{\mathrm{AR}}\right), 124.8\left(\mathrm{CH}_{\mathrm{AR}}\right), 128.4-131.7$ $\left(\mathrm{CH}_{\mathrm{AR}}\right), 134.1(\mathrm{CH}=), 136.8\left(\mathrm{C}_{\mathrm{AR}}\right), 137.8\left(\mathrm{C}_{\mathrm{AR}}\right), 146.1(\mathrm{CH}=), 153.2(\mathrm{CO})$, 162.1 (CO), 168.9 (CO), 192.5 (CO) ppm.

596 Minor Isomer: ${ }^{1} \mathrm{H}$ NMR $\left(400 \mathrm{MHz}, \mathrm{CDCl}_{3}, \mathrm{COSY}, g\right.$-HSQC, $\left.25^{\circ} \mathrm{C}, \mathrm{TMS}\right)$ : $\delta=1.44\left[\mathrm{~s}, 9 \mathrm{H},\left(\mathrm{CH}_{3}\right)_{3}\right], 1.52(\mathrm{~m}, 1 \mathrm{H}, 1-\mathrm{H}), 1.77\left[\mathrm{~s}, 9 \mathrm{H},\left(\mathrm{CH}_{3}\right)_{3}\right], 1.97$ (ddd, $\left.J=11.6,7.2,1.6 \mathrm{~Hz}, 3 \mathrm{H}, \mathrm{CH}_{3}\right), 2.72(\mathrm{~m}, 1 \mathrm{H}, 1-\mathrm{H}), 2.91(\mathrm{~m}, 2$ $\mathrm{H}, 7-\mathrm{H}), 3.70(\mathrm{~m}, 1 \mathrm{H}, 2-\mathrm{H}), 3.72\left(\mathrm{~s}, 3 \mathrm{H}, \mathrm{CH}_{3} \mathrm{O}\right), 4.00\left(\mathrm{~m}, 1 \mathrm{H}, \mathrm{CH}_{2} \mathrm{O}\right)$, $4.02(\mathrm{~d}, J=6.0 \mathrm{~Hz}, 1 \mathrm{H}, 3-\mathrm{H}), 4.17\left(\mathrm{~m}, 1 \mathrm{H}, \mathrm{CH}_{2} \mathrm{O}\right), 4.45(\mathrm{~d}, J=6.0 \mathrm{~Hz}$,

$6011 \mathrm{H}, \mathrm{CHCOO}), 5.34-5.44(\mathrm{~m}, 2 \mathrm{H}, 6-\mathrm{H}, 12-\mathrm{Hb}), 6.20-6.28(\mathrm{~m}, 1 \mathrm{H}$, $\mathrm{CH}=), 6.92-7.05(\mathrm{dq}, J=15.8,6.8 \mathrm{~Hz}, 1 \mathrm{H}, \mathrm{CH}=), 7.23-7.33(2 \mathrm{~m}, 2$ $\left.\mathrm{H}, \mathrm{H}_{\mathrm{AR}}\right), 7.41\left(\mathrm{dm}, J=8.0 \mathrm{~Hz}, 1 \mathrm{H}, \mathrm{H}_{\mathrm{AR}}\right), 7.57\left(\mathrm{~m}, 2 \mathrm{H}, \mathrm{H}_{\mathrm{AR}}\right), 7.68(\mathrm{~m}$, $\left.1 \mathrm{H}, \mathrm{H}_{\mathrm{AR}}\right), 7.99\left(\mathrm{~m}, 2 \mathrm{H}, \mathrm{H}_{\mathrm{AR}}\right), 8.15\left(\mathrm{~d}, J=8.0 \mathrm{~Hz}, 1 \mathrm{H}, \mathrm{H}_{\mathrm{AR}}\right) \mathrm{ppm} .{ }^{13} \mathrm{C}$ NMR (100.6 MHz, CDCl, $25^{\circ} \mathrm{C}$, TMS): $\delta=18.5\left(\mathrm{CH}_{3}\right), 21.5(\mathrm{C}-7), 27.7$ $606\left[\left(\mathrm{CH}_{3}\right)_{3} \mathrm{C}\right], 28.3\left[\left(\mathrm{CH}_{3}\right)_{3} \mathrm{C}\right], 31.2(\mathrm{C}-2), 36.0(\mathrm{C}-1), 45.6,50.9(\mathrm{C}-6, \mathrm{C}-12 \mathrm{~b})$, $52.7\left(\mathrm{CH}_{3} \mathrm{O}\right), 58.4(\mathrm{C}-3), 65.5\left(\mathrm{CH}_{2} \mathrm{O}\right), 68.9(\mathrm{CHCOO}), 82.3\left[\left(\mathrm{CH}_{3}\right)_{3} \mathrm{C}\right]$, $85.1\left[\left(\mathrm{CH}_{3}\right)_{3} \mathrm{C}\right], 113.6\left(\mathrm{C}_{\mathrm{AR}}\right), 116.0\left(\mathrm{C}_{\mathrm{AR}}\right), 118.0\left(\mathrm{CH}_{\mathrm{AR}}\right), 123.0\left(\mathrm{CH}_{\mathrm{AR}}\right)$, $124.8\left(\mathrm{CH}_{\mathrm{AR}}\right), 128.4-131.7\left(\mathrm{CH}_{\mathrm{AR}}\right), 133.9(\mathrm{CH}=), 136.9\left(\mathrm{C}_{\mathrm{AR}}\right), 138.1$ $\left(\mathrm{C}_{\mathrm{AR}}\right), 145.4(\mathrm{CH}=), 149.8(\mathrm{CO}), 162.3(\mathrm{CO}), 168.5(\mathrm{CO}), 192.6(\mathrm{CO})$ $611 \mathrm{ppm}$.

Computational Methods: Full geometry optimizations were performed with the M06-2X $X^{[16]}$ density functional method by using the $6-31 G(d)^{[17]}$ basis set. The nature of the stationary points was verified by inspection of the vibrational frequencies within the har616 monic oscillator-rigid rotor approximation. In specific cases, the free-energy profile of the annulation reactions was determined from single-point calculations performed at the spin-component scaled MP2 (SCS-MP2) ${ }^{[25]}$ level with the $6-31 \mathrm{G}(\mathrm{d})$ basis, and from B2PLYPD3 $^{[26]}$ calculations with the def2-SVPP ${ }^{[27]}$ basis. These meth-

621 ods have proved valuable for the study of reactive processes. ${ }^{[28]}$ The relative free energies were estimated by combining the energy differences with the thermal/entropy corrections derived from frequency analysis. To this end, the free energy corrections were calculated by using Truhlar's quasiharmonic approximation, ${ }^{[29,30]}$ where

626 real harmonic vibrational frequencies lower than $100 \mathrm{~cm}^{-1}$ were raised to $100 \mathrm{~cm}^{-1}$, as has been utilized in other chemical reactivity studies. ${ }^{[31-33]}$ Finally, the effect of solvation in dichloromethane was taken into account using the SMD version ${ }^{[18]}$ of the IEF-PCM ${ }^{[31]}$ continuum solvation method. SMD calculations were performed the

$631 \mathrm{~B} 3 \mathrm{LYP} / 6-31 \mathrm{G}(\mathrm{d})^{[35]}$ level, which was one of the six electronic structure methods used in the optimization of the SMD method. All DFT computations were carried out using the keyword Integral(Grid = Ultrafine) as implemented in Gaussian 09, ${ }^{[36]}$ which was used to carry out these calculations.

\section{Acknowledgments}

Financial support from the MINECO/FEDER, Spain (projects SAF2014-57094-R, CTQ2015-65384-R, ENE2015-63969, and SEV2015-0496) and the Generalitat de Catalunya (grants 2014SGR-0155 and 2014SGR-1189) is gratefully acknowledged. 641 Thanks are also due to the MINECO (Spain) for fellowships to
F. A. (AP2010-1663) and C. E. (FPDI-2013-15572), the Icrea Academia for financial support to F. J. L., and the Leonardo da Vinci Programme (Unipharma-Graduates 9) for a mobility grant to C. A. We also acknowledge the Consorci de Serveis Universitaris de Catalunya (CSUC) for their computational facilities, as well as 646 the networking contribution from the COST Action (CM1407).

Keywords: Density functional calculations . Michael addition - Nazarov reagent · Density functional calculations Stereoselectivity

[1] a) First reported by: I. N. Nazarov, S. I. Zavyalov, Zh. Obshch. Khim. 1953, 651 23, 1703; J. Gen. Chem. Engl. Transl. 1953, 23, 1793; Chem. Abstr. 1954, 48, 13667h; for improved preparations, see: b) R. Zibuck, J. M. Streiber, J. Org. Chem. 1989, 54, 4717-4719; c) R. Zibuck, J. M. Streiber, Org. Synth. 1993, 71, 236-241 and references cited therein.

[2] For reviews, see: a) R. Zibuck in Encyclopedia of Reagents for Organic 656 Synthesis, vol. 5 (Ed.: L. A. Paquette), Wiley, Chichester, 1995, pp. 35583559; b) G. Audran, P. Brémond, M. Feuerstein, S. R. A. Marque, M. Santelli, Tetrahedron 2013, 69, 8325-8348.

[3] Molecules that contain both a nucleophilic and an electrophilic site have been referred to as amphoteric, see: a) T. B. Samarakoon, M. Y. Hur, R. D. 661 Kurtz, P. R. Hanson, Org. Lett. 2010, 12, 2182-2185; b) for a review, see: Z. He, A. Zajdlik, A. K. Yudin, Acc. Chem. Res. 2014, 47, 1029-1040.

[4] a) J. E. Ellis, J. S. Dutcher, C. H. Heathcock, Synth. Commun. 1974, 4, 7177; b) Y. Hoashi, T. Yabuta, P. Yuan, H. Miyabe, Y. Takemoto, Tetrahedron 2006, 62, 365-374; c) S. Benetti, S. Carli, C. De Risi, G. P. Pollini, A. C. 666 Veronese, V. Zanirato, Synlett 2008, 2609-2612; d) C.-H. Tu, Y.-K. Wu, K.S. Shia, S.-C. Kuo, H.-J. Liu, M.-T. Hsieh, Synlett 2014, 25, 543-546; see also ref. ${ }^{[2 a]}$

[5] a) P. Pollet, S. Gelin, Synthesis 1978, 142-143; b) R. Zibuck in Encyclopedia of Reagents for Organic Synthesis, vol. 2 (Ed.: L. A. Paquette), Wiley, Chi- 671 chester, 1995, pp. 936-937.

[6] a) J.-F. Lavallée, P. Deslongchamps, Tetrahedron Lett. 1988, 29, 5117-5118; b) J.-F. Lavallée, C. Spino, R. Ruel, K. T. Hogan, P. Deslongchamps, Can. J. Chem. 1992, 70, 1406-1426; for examples on the use of alkyl-substituted Nazarov reagents in the synthesis of complex polycyclic systems, see: c) 676 R. Ruel, P. Deslongchamps, Can. J. Chem. 1992, 70, 1939-1949; d) M. S. Reddy, H. Zhang, S. Phoenix, P. Deslongchamps, Chem. Asian J. 2009, 4, 726-741; for recent applications, including organocatalytic Robinson annulations, see: e) B. Berkes, K. Ozsváth, L. Molnár, T. Gáti, T. Holczbauer, G. Kardos, T. Soós, Chem. Eur. J. 2016, 22, 18101-18106.

[7] M. Amat, F. Arioli, M. Pérez, E. Molins, J. Bosch, Org. Lett. 2013, 15, 2470 2473.

[8] F. Arioli, M. Pérez, C. Are, C. Estarellas, J. L. Luque, J. Bosch, M. Amat, Chem. Eur. J. 2015, 21, 13382-13389.

[9] Similar differences in the facial selectivity have been observed in conju- 686 gate addition reactions to $N_{\text {ind }}$-unsubstituted and $N_{\text {ind }}$-Boc-subatituted indoloquinolizidine lactams, see: a) S. M. Allin, J. S. Khera, C. I. Thomas, J. Witherington, K. Doyle, M. R. J. Elsegood, M. Edgar, Tetrahedron Lett. 2006, 47, 1961-1964; b) S. M. Allin, J. S. Khera, J. Witherington, M. R. J. Elsegood, Tetrahedron Lett. 2006, 47, 5737-5739; c) A. Deiters, M. Petters- 691 son, S. F. Martin, J. Org. Chem. 2006, 71, 6547-6561.

[10] For DBU-promoted stereoselective annulation reactions with the original Nazarov reagent, see ref. ${ }^{[4 d]}$

[11] Minor amounts (ca. $5 \%$ ) of the corresponding $3-\mathrm{H} / 15-\mathrm{H}$ trans isomer were also isolated.

[12] Another stereoisomer, with a $3-\mathrm{H} / 15-\mathrm{H}$ cis stereochemistry, was isolated in $19 \%$ yield.

[13] The absolute configurations of compounds $9 \mathbf{a}$ and 10a were unambiguously determined by X-ray crystallographic analysis. CCDC 1528357 (for 9a), and 1528358 (for 10a) contain the supplementary crystallographic 701 data for this paper. These data can be obtained free of charge from The Cambridge Crystallographic Data Centre.

[14] This stereochemical outcome is the same as that found in related annulations of the methyl-substituted Nazarov reagent 2 with 2-(methoxycarbonyl)-2-cyclohexenones; see refs. ${ }^{[6 a, 6 b]}$ 
[15] a) For the stereoselective generation of cis/trans-decaline adducts in the base-catalyzed double Michael addition of the $\beta$-keto phenylsulfinyl (or -sulfonyl) analogues of $\mathbf{4}$ to 2-(methoxycarbonyl)-2-cyclohexenone, see: C. Spino, P. Deslongchamps, Tetrahedron Lett. 1990, 31, 3969-3972. See also: b) G. Berthiaume, J.-F. Lavallée, P. Deslongchamps, Tetrahedron Lett. 1986, 27, 5451-5454.

[16] Y. Zhao, D. G. Truhlar, Theor. Chem. Acc. 2008, 120, 215-241.

[17] P. C. Hariharan, J. A. Pople, Theor. Chim. Acta 1973, 28, 213-218.

[18] A. V. Marenich, C. J. Cramer, D. G. Truhlar, J. Phys. Chem. B 2009, 113, 716 6378-6396.

[19] C. Mayeux, L. Massi, J.-F. Gal, L. Charles, P. Burk, Chem. Eur. J. 2014, 20, 815-823.

[20] E. S. Vikulova, K. V. Zherikova, N. V. Kuratieva, N. B. Morozova, I. K. Igumenov, J. Coord. Chem. 2013, 66, 2235-2249.

721 [21] A. Facchetti, A. Streitwieser, J. Org. Chem. 2004, 69, 8345-8355.

[22] For the stereoselective removal of a phenylsulfonyl group placed at the $\alpha$-position of a lactam carbonyl group, see: Y. C. Jung, C. H. Yoon, E. Turos, K. S. Yoo, K. W. Jung, J. Org. Chem. 2007, 72, 10114-10122.

[23] a) S. M. Allin, C. I. Thomas, J. E. Allard, K. Doyle, M. R. J. Elsegood, Tetrahedron Lett. 2004, 45, 7103-7105; b) S. M. Allin, C. I. Thomas, K. Doyle, M. R. J. Elsegood, J. Org. Chem. 2005, 70, 357-359; c) M. Amat, C. Ramos, M. Pérez, E. Molins, P. Florindo, J. Bosch, Chem. Commun. 2013, 49, 19541956.

[24] W. J. Scott, J. K. Stille, J. Am. Chem. Soc. 1986, 108, 3033-3044.

731 [25] S. Grimme, J. Chem. Phys. 2003, 118, 9095-9102.

[26] a) S. Grimme, J. Chem. Phys. 2006, 124, 034108; b) S. Grimme, S. Ehrlich, L. Goerigk, J. Comput. Chem. 2011, 32, 1456-1465.

[27] F. Weigend, R. Ahlrichs, Phys. Chem. Chem. Phys. 2005, 7, 3297-3305.

[28] S. Grimme, L. Goerigk, R. F. Fink, WIRES Comput. Mol. Sci. 2012, 2, 886736906.

[29] Y. Zhao, D. G. Truhlar, Phys. Chem. Chem. Phys. 2008, 10, 2813-2818.
[30] R. F. Ribeiro, A. V. Marenich, C. J. Cramer, D. G. Truhlar, J. Phys. Chem. B 2011, 115, 14556-14562.

[31] A. H. Asari, Y.-H. Lam, M. A. Tius, K. N. Houk, J. Am. Chem. Soc. 2015, 137, 13191-13199.

[32] N. Gulzar, K. M. Jones, H. Konnerth, M. Breugst, M. Klussmann, Chem. Eur. J. 2015, 21, 3367-3376.

[33] K. G. Kishore, O. Ghashghaei, C. Estarellas, M. M. Mestre, C. Monturio, N. Kielland, J. M. Kelly, A. F. Francisco, S. Jayawardhana, D. Muñoz-Torrero, B. Pérez, F. J. Luque, R. Gámez-Montaño, R. Lavilla, Angew. Chem. Int. Ed. 746 2016, 55, 8994-8998; Angew. Chem. 2016, 128, 9140.

[34] E. Cancès, B. Mennucci, J. Tomasi, J. Chem. Phys. 1997, 107, 3032-3041. ( $1<=$ AUTHOR: Ref. [34] is not cited in the text; please check!))

[35] a) A. D. Becke, Phys. Rev. A 1988, 38, 3098-3100; b) C. Lee, W. Yang, R. G. Parr, Phys. Rev. B 1988, 37, 785-789; c) P. J. Stephens, F. J. Devlin, C. F. 751 Chabalowski, M. J. Frisch, J. Phys. Chem. 1994, 98, 11623-11627.

[36] M. J. Frisch, G. W. Trucks, H. B. Schlegel, G. E. Scuseria, M. A. Robb, J. R. Cheeseman, G. Scalmani, V. Barone, B. Mennucci, G. A. Petersson, H. Nakatsuji, M. Caricato, X. Li, H. P. Hratchian, A. F. Izmaylov, J. Bloino, G. Zheng, J. L. Sonnenberg, M. Hada, M. Ehara, K. Toyota, R. Fukuda, J. Hase- 756 gawa, M. Ishida, T. Nakajima, Y. Honda, O. Kitao, H. Nakai, T. Vreven, J. A. Montgomery Jr., J. E. Peralta, F. Ogliaro, M. Bearpark, J. J. Heyd, E. Brothers, K. N. Kudin, V. N. Staroverov, R. Kobayashi, J. Normand, K. Raghavachari, A. Rendell, J. C. Burant, S. S. lyengar, J. Tomasi, M. Cossi, N. Rega, J. M. Millam, M. Klene, J. E. Knox, J. B. Cross, V. Bakken, C. Adamo, J. 761 Jaramillo, R. Gomperts, R. E. Stratmann, O. Yazyev, A. J. Austin, R. Cammi, C. Pomelli, J. W. Ochterski, R. L. Martin, K. Morokuma, V. G. Zakrzewski, G. A. Voth, P. Salvador, J. J. Dannenberg, S. Dapprich, A. D. Daniels, Ö. Farkas, J. B. Foresman, J. V. Ortiz, J. Cioslowski, D. J. Fox, Gaussian 09, revision C.01, Gaussian, Inc., Wallingford, CT, 2010.

Received: May 2, 2017 


\section{Stereoselectivity}

C. Estarellas, F. Arioli, M. Pérez,

C. Are, D. Hevia, E. Molins,

771 F. J. Luque, ${ }^{*}$ J. Bosch,

M. Amat*

$1-12$

Origin of the Base-Dependent Facial

(D) Selectivity in Annulation Reactions 776 of Nazarov-Type Reagents with Unsaturated Indolo[2,3-a]quinolizidine Lactams

78

Authors: Please check that the ORCID identifiers listed below are correct. We encourage all authors to provide an ORCID identifier for each coauthor. ORCID is a registry that provides researchers with a unique digital identifier. Some funding 786 agencies recommend or even require the inclusion of ORCID IDs in all published articles, and authors should consult their funding agency guidelines for details. Registration is easy and free; for further information, see http://orcid.org/.

Carolina Estarellas

Federica Arioli

Maria Pérez http://orcid.org/0000-0001-5775-6472

791 Celeste Are

David Hevia

Elies Molins

F. Javier Luque http://orcid.org/0000-0002-8049-3567*

Joan Bosch http://orcid.org/0000-0001-5974-1733

796 Mercedes Amat http://orcid.org/0000-0002-9551-4690*

\section{DOI: 10.1002/ejoc.201700610}

